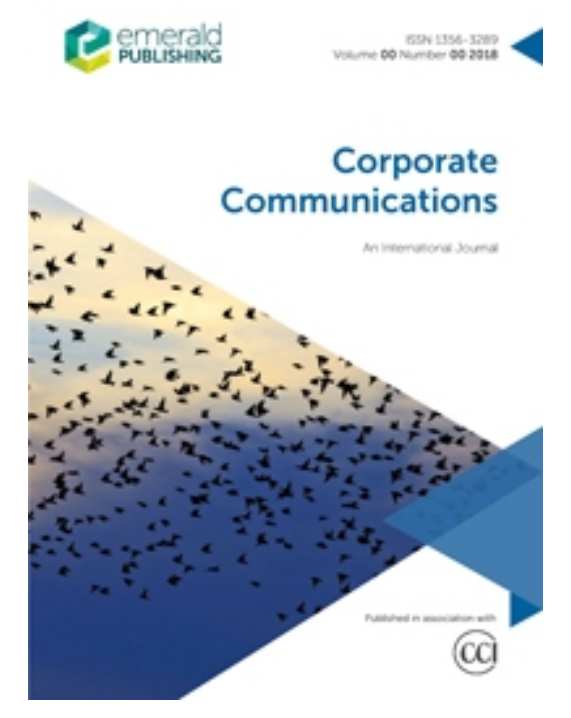

\title{
ONLINE SUSTAINABILITY INFORMATION DISCLOSURE OF MOULD COMPANIES
}

\begin{tabular}{|r|l|}
\hline Journal: & Corporate Communications: an International Journal \\
\hline Manuscript ID & CCIJ-05-2020-0085.R1 \\
\hline Manuscript Type: & Original Article \\
\hline Keywords: & $\begin{array}{l}\text { Sustainability information, moulds industry, content analysis, Disclosure, } \\
\text { websites }\end{array}$ \\
\hline
\end{tabular}

\section{SCHOLARONE ${ }^{m}$ \\ Manuscripts}

The final version of this article is available online at

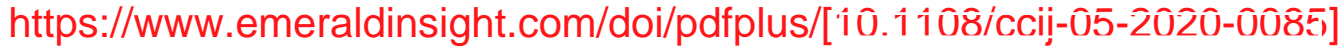




\title{
ONLINE SUSTAINABILITY DISCLOSURE OF MOULD COMPANIES
}

\begin{abstract}
Purpose: To improve the understanding of the online sustainability disclosure phenomena considering the quantity and nature of the content of the information related to sustainability disclosed in the corporate website of companies; providing evidence about the website sustainability disclosure of different size companies and; characterizing the website sustainability disclosure of the Portuguese mould companies.
\end{abstract}

Design/methodology/approach: A content analysis methodology was used to the corporate websites of 83 companies in the sample. A direct approach was followed where the researcher is asked to read and classify the text in a previously defined category, but where the possibility of identifying new categories from the collected data is not excluded.

Findings: The information on sustainability disclosed by the mould companies is limited, whether in quantity or concerning the type of information. The information disclosed about environmental and social aspects is scarcer, being the focus more on aspects related to the economic dimension of sustainability, particularly in the areas related to products and services and customers.

Research limitations/implication: The research design can be broadened to include other sustainability dissemination tools and other research methodologies, such as case studies, to provide a deeper understanding of the concerns and initiatives/practices of sustainability of mould companies.

Practical implications: This study contributes to the knowledge of sustainability dissemination practices in SMEs, an area of research that needs to be more explored and, in an industrial sector (moulds) that have not received much attention in this area.

Originality/value: Based on the premise of the importance of corporate sustainability communication, the study focuses on the Internet as an information dissemination tool. It provides indications on the theme and information type that can be used to report the company's sustainability.

Keywords: sustainability information, moulds industry, content analysis, disclosure, websites 


\section{INTRODUCTION}

The literature shows a growing interest in corporate sustainability which is defined as "... meeting the needs of a company's direct and indirect stakeholders (such as shareholders, employees, clients, pressure groups, communities etc.), without compromising its ability to meet the needs of future stakeholders as well" (Dyllick and Hockerts, 2002, p.131). The concept of corporate sustainability is rooted in the notion of sustainable development since it captures the company desire to achieve long-term sustainability, supporting the continuous improvement of social, environmental, and economic conditions (Steurer et al., 2005). To achieve sustainable development goals and meet the stakeholders' expectations, companies need to embed sustainability strategies into their procedures and business practices (Siano et al., 2016).

As mentioned by Joseph and Taplin (2011) external communication and reporting play an important role in company sustainability. The increased focus on organizational accountability and transparency has led companies to show the stakeholders their higher level of concern about sustainability issues and good corporate governance (transparency, accountability, responsibility, and fairness) (Okongwu et al., 2013). Moreover, many regulations, guidelines, and initiatives express a need for corporate transparency, not only about financial issues but also about the social and environmental aspects (Maas et al., 2016). Being so, it is crucial to report and communicate the sustainability relevant issues and activities correctly. Sustainability reporting is: "the practice of measuring, disclosing and being accountable to internal and external stakeholders for organisational performance towards the goal of sustainable development" (Srai et al., 2013, p. 599).

Research on sustainability reporting has mainly focused on annual reports and examination of stand-alone sustainability reports (Mura et al., 2019). Considering that companies use a wider variety of communication channels to disclose information, it seems important to analyze other types of tools used to disseminate sustainability information. Branco et al. $(2014$, p. 1) highlight that the Internet particularly "has become an important medium through which companies can disclose information of different natures and corporate internet reporting is a fast-growing area of interest". Sustainability reporting via online communication, also designated by "online sustainability disclosure" (Amran et al., 2015). This type of disclosure refers to the communication of any sustainability-related information online via the Internet, particularly on websites (Rahim and Omar, 2017). In this paper, we use the term "sustainability" in the business context and "online sustainability disclosure" when referring to all type of corporate information about sustainability issues, including the corporate social responsibility, that is communicated by companies through their website

The Internet has been developed as a key communication channel for disseminating corporate sustainability information since the late 1990s (Guthrie et al., 2008; Campbell, 2004). Many studies have been developed about the use of the Internet to communicate the sustainability efforts of a company (e.g., Campbell and Beck, 2004; Cormier and Magnan, 2003; Rikhardsson et al., 2002). In a content analysis for Malaysian Authorities made by Joseph (2010), the use of the Internet as a means of communication was studied; it was concluded that $92.1 \%$ of the organizations in the sample are not endorsing the environmental issues in their websites. This means that they are not using their websites entirely to communicate such issues. That study was later extended to Malaysian Hotel websites by Joseph et al. (2014); their results showed that, on average, only $14.7 \%$ of the Hotels discloses information related to sustainability. So, there is a need to find out how web-based communication can be used to support the companies' sustainability-related communication with the stakeholder.

Mura et al. (2019) point out that most research in sustainability' disclosure focuses on formal reporting schemes and mainly in large organizations' context. For example, Ramos et al. (2013) studied the adoption of environmental and sustainability reporting practices in Portuguese larger companies. To avoid a biased analysis of this issue, it is necessary to do further studies to analyze the sustainability disclosure in small and medium-sized (SMEs) companies. Recently, Dias et al. (2019) have analyzed the disclosure of corporate social responsibility practices of 57 Portuguese companies of different sizes and analyze whether business characteristics influence its disclosure strategies. Others research settings include different units of analysis, such as the type of organizations (e.g., Chaudhri and Wang, 2007; Dincer and Dincer, 2010), including non-profit organizations (e.g., Tremblay-Boire, 2014), and in diverse countries' context, from developed countries such as Australia, France, England, or United States, to less developed countries such as Turkey, China, or Malaysia (Bae et al., 2018)

The present study focuses on the sustainability disclosure of the mould companies in Portugal. The mould industry is considered very dynamic and innovative, with a high technical and technological level (Marques, 2017). Large multinationals (e.g., automotive, packaging, electronics/telecommunications, and home appliances) select Portuguese companies to be their mould's suppliers. The automotive sector is one of the 
Portuguese mould industry's major customers (CEFAMOL, 2014). It is considered a key stakeholder because of the automaker's quest for sustainability (Thun and Müller, 2010), so the sustainability concerns need to be integrated into their strategies, operations, and supply chain management, which includes the moulds suppliers. Portugal is one of the world's leading manufacturers in the moulds industry: in terms of exportation, it ranks third place in Europe and the eighth in the world (AICEP, 2018). Little is known about the sustainability behaviour of companies in this industry because there is a lack of dissemination of sustainability' information. So, this work seeks to fill this gap in the literature.

Considering the above discussion, this paper main objective is to contribute to a bigger understanding of the online sustainability disclosure phenomena in three facets: (i) giving insights on the quantity and nature of the content of the information related to sustainability disclosed in the corporate website of companies; (ii) providing evidence about the website sustainability disclosure of different size companies; (iii) characterizing the website sustainability disclosure of the Portuguese mould companies.

This paper is organized as follows. Section 2 performs a literature review on disclose sustainability information. In Section 3, the research questions are described. Section 4 describes the research methodology followed in this study. Section 5 describes and discusses the main results. Finally, in Section 6 , some conclusions are drawn.

\section{BACKGROUND}

\subsection{Disclosing sustainability information}

Sustainable development has become a popular discussion topic in all sectors since 1987 when this concept was introduced in the Brundtland Commission Report (Virakul and Russ-Eft, 2020). Since then, the scope of sustainable development was both broadened and deepened. The economic, social, and environmental issues evolved into equally important dimensions within the "triple bottom line" (TBL) performance and the concept was expanded from the macroeconomic to the microeconomic and individual level (Steurer et al., 2005). At the organizational level, sustainable development is addressed as corporate sustainability (Steurer et al., 2005). While the sustainable development is a societal model, the "corporate sustainability is a corporate guiding model, addressing the short and long-term economic, social and environmental performance of corporations" (Steurer et al., 2005, p. 274). To achieve the goals of sustainable development, companies must focus on economic performance, environmental and social well-being in balanced, holistic, and long-term ways (Virakul and Russ-Eft, 2020).

Corporate social responsibility is another concept used to express corporate transition to sustainability (Ashrafi et al, 2018; Steurer et al., 2005). Corporate social responsibility is considered as a commitment of a company to go beyond the economic priorities, to build a good relationship with the stakeholders, and to maintain transparency and ethical behaviour (Dincer and Dincer, 2010). The European Commission defines corporate social responsibility as:

"the responsibility of enterprises for their impacts on society ... to integrate social, environmental, ethical, human rights and consumer concerns into their business operations and core strategy" (European Commission, 2001, p. 6).

As there is no universally accepted definition, and despite their paradigmatic differences, corporate sustainability and corporate social responsibility are often considered synonyms and often used interchangeably (Reilly and Larya, 2018). The two concepts share some aspects, for example, they are both "voluntary business activities" and aim to contribute to a better performance of companies in the TBL dimension (Steurer et al., 2005). Both concepts of corporate sustainability and corporate social responsibility have recently come to converge (Montiel, 2008; Ashrafi et al, 2018). However, some researchers understand that corporate social responsibility and corporate sustainability are different concepts, considering, for example, corporate social responsibility is just targeting the social aspect of corporate sustainability. This is the case of Linnenluecke et al. (2009) which highlights the social aspect where the company (i) pays attention to its internal staff development, (ii) attempts to deal proactively with its community base, and (iii) engages with its stakeholder. Das et al. (2020) also consider that the concept of corporate social responsibility mainly focuses on charity and philanthropic activities.

Bansal (2005) considers that corporate sustainability is achieved only by the intersection of the following three principles: environmental integrity (through environmental management of enterprises), social equity (through corporate social responsibility), and economic prosperity (through value creation). These three principles are aligned with the TBL perspectives that companies need to pursuit to become more sustainable. Epstein (2008) proposes nine principles for companies to achieve sustainable development: 
ethics, governance, transparency, business relationships, financial returns, community involvement, the value of products and services for clients, protection. Each sustainability principle can be put into action through some practices. For example, to minimize and mitigate environmental impacts, companies can undertake initiatives such as using green materials, renewable energy for lighting and transportation, recycling or reuse of all waste, or applying leadership to influence the industry, that is, buying green energy or green materials from suppliers to drive the industry (Hitchcock and Willard, 2006). To contribute to community development, companies can also take a proactive and cooperative role in creating a community that is both a good place to live and conduct business. In this way, the sustainable development or sustainability values need to be embedded in all aspects of the company, in the different functional areas and activities, including in those involving supply chain partners (Seuring and Gold, 2013) and other stakeholders such as ONG's. One way that companies use to evolve the stakeholders is by reporting their sustainability practices and performance.

A theory that is widely used to explain sustainability reporting and disclosure is the stakeholder's theory (Gray et al., 1995; O' Dwyer, 2003). The stakeholder theory clusters the society into groups, called stakeholders, that have expectations related to the companies' performance and behaviour. Such a theory provides the mechanism that will hold companies to be accountable for their actions (Lodia, 2010). According to Freeman and Reed (1983), a stakeholder is defined as "any identifiable group or individual who can affect the achievement of an organization's objectives." Under this theoretical lens:

“the corporation's continued existence requires the support of the stakeholders and their approval must be sought, and the activities of the corporation adjusted to gain that approval. The more powerful the stakeholders, the more the company must adapt" (Gray et al., 1995, p. 53).

Companies are increasingly considering their responsibility and the impact of their actions on stakeholders (Solomon, 2010). To respond to the stakeholder's request for more sustainable business development, companies voluntarily integrate into their organizational structure and governance ways to address the social and environmental concerns (Marrewijk, 2003). Companies should consider the stakeholder's different expectations and perspectives regarding various environmental, social, corporate governance, and economic issues and integrate those expectations and views in their strategic decision-making processes (Hamzah and Abdullah, 2018). To meet the increased interest of the stakeholder's many companies, in a voluntary way, disclose sustainability information to communicating their progress and efforts regarding its sustainability actions (Dienes et al., 2016). This is in line with the stakeholder theory that argues that companies try to respond to stakeholders' expectations through their corporate social responsibility communications channels (Barako and Brown, 2008).

Sustainability disclosure covers information related to economic, environmental, social, and governance performance to stakeholders (Rahim and Omar, 2017). The lack of sustainability disclosure can be understood as evidence of a company' poor condition and thus negatively impact stakeholder's decisions (Joshi and Gao, 2009). Information disclosure can be used as a tool to improve their relationships with society and their stakeholders, including suppliers, creditors, activist groups, the government, the media, customers as well as the general public (Bae et al., 2018). Society, in general, has shown great interest in corporate social responsibility and on the behaviour of business practices transparency (Servera-Francês and Arteaga-Moreno, 2015). By disclosing sustainability information, companies aim to increase transparency and enhance reputation and legitimacy and ensure positive stakeholder support (Raghupathi and Raghupathi, 2019). Besides that, disclosing sustainability information attracts better employees and increases their motivation, commitment, and loyalty, which is translated into financial benefits (Branco and Rodrigues, 2008). Qian et al. (2020) also highlight that corporate sustainability reporting provides an opportunity for companies to distinguish themselves from competitors in the global marketplace, and this can become a major driver for sustainability reporting. Another study considering organizations in the IndoPacific region, defend "reputation" has a major influence on sustainability reporting. The "regulatory requirements" and "top management commitment and expectation" were also identified as major internal moral drivers for sustainability change.

In line with Steurer et al. (2005) and Ashrafi et al. (2018), we consider that although close, there are some differences between corporate sustainability and corporate social responsibility, namely concerning their scope and the variable time frame. Despite the existence of several studies about sustainability reporting, there is an ambiguity and disagreement in the terminology used by companies to report their sustainability efforts. Omoloso et al. (2020, p. 46) referred explicitly to this misunderstanding: "in different organisational contexts, sustainability reporting has been similarly referred to corporate social responsibility reporting, triple bottom line reporting, non-financial reporting, sustainable development reporting, environmental, social and governance reporting". As noticed by Ashrafi et al. (2018) companies can adopt different 
designations to their corporate sustainability reporting such as "sustainability reports", "social reports", "corporate social responsibility reports", "corporate citizenship reports", and even "corporate responsibility reports". In addition to this difficulty of companies to properly categorize their sustainability disclosure, in the scientific literature, we also find some overlap between the topics analyzed in the corporate sustainability and corporate social responsibility disclosure (Carvalho, 2013). Table 1 provides an overview of the variety of topics used in online sustainability disclosure.

Table 1 - Online sustainability disclosure research

\begin{tabular}{|c|c|c|c|c|c|c|c|c|c|c|c|c|}
\hline \multirow[b]{2}{*}{ Topics } & \multirow{2}{*}{$\begin{array}{l}\text { Ehsan } \\
\text { et al. } \\
\text { (2018) }\end{array}$} & \multicolumn{4}{|c|}{ Corporate sustainability } & \multirow[b]{2}{*}{$\begin{array}{l}\text { Ho and } \\
\text { Taylor } \\
(2007)\end{array}$} & \multicolumn{6}{|c|}{ Corporate social responsibility } \\
\hline & & $\begin{array}{c}\text { Tang et } \\
\text { al., } \\
(2015)\end{array}$ & $\begin{array}{c}\text { Sobhani } \\
\text { et al. } \\
(2012)\end{array}$ & $\begin{array}{l}\text { Correia } \\
(2010)\end{array}$ & $\begin{array}{c}\text { Tagesson } \\
\text { et al. } \\
(2009)\end{array}$ & & $\begin{array}{l}\text { Capriotti } \\
\text { and } \\
\text { Moreno } \\
(2007)\end{array}$ & $\begin{array}{l}\text { Raghupathi } \\
\text { and } \\
\text { Raghupathi, } \\
2019\end{array}$ & $\begin{array}{c}\text { Branco and } \\
\text { Rodrigues } \\
(2006, \\
2008)\end{array}$ & $\begin{array}{c}\text { Kühn et } \\
\text { al. } \\
(2018)\end{array}$ & $\begin{array}{c}\text { Van der } \\
\text { Laan et } \\
\text { al. } \\
(2005)\end{array}$ & $\begin{array}{c}\text { Gray et } \\
\text { al. } \\
(1995)\end{array}$ \\
\hline Community welfare & $\mathrm{x}$ & & $\mathrm{x}$ & $\mathrm{x}$ & & $\mathrm{x}$ & & & $\mathrm{x}$ & $\mathrm{x}$ & $\mathrm{x}$ & $\mathrm{x}$ \\
\hline Education and health & $\mathrm{x}$ & $\mathrm{x}$ & & & & & & & & & $\mathrm{x}$ & \\
\hline Social action & & & & & & & $\mathrm{x}$ & & & & $\mathrm{x}$ & \\
\hline Diversity & & & & $\mathrm{x}$ & & $\mathrm{x}$ & & & & & & \\
\hline Human rights & & & $\mathrm{x}$ & $\mathrm{x}$ & $\mathrm{x}$ & $\mathrm{x}$ & $\mathrm{x}$ & & & & & \\
\hline $\begin{array}{l}\text { Workforce / Human } \\
\text { resources }\end{array}$ & $\mathrm{x}$ & $\mathrm{x}$ & $\mathrm{x}$ & $\mathrm{x}$ & $\mathrm{x}$ & $\mathrm{x}$ & $\mathrm{x}$ & & $\mathrm{x}$ & $\mathrm{x}$ & $\mathrm{x}$ & $\mathrm{x}$ \\
\hline Health and safety & & & & $\mathrm{x}$ & & & & & $\mathrm{x}$ & & & \\
\hline Customer/consumers & $\mathrm{x}$ & & & $\mathrm{x}$ & & $\mathrm{x}$ & & & $\mathrm{x}$ & & $\mathrm{x}$ & $\mathrm{x}$ \\
\hline Suppliers & & & & & & $\mathrm{x}$ & & & & & & \\
\hline Product and services & $\mathrm{x}$ & & $\mathrm{x}$ & $\mathrm{x}$ & & & $\mathrm{x}$ & $\mathrm{x}$ & $\mathrm{x}$ & $\mathrm{x}$ & $\mathrm{x}$ & \\
\hline Environmental impact & $\mathrm{x}$ & & $\mathrm{x}$ & $\mathrm{x}$ & $\mathrm{x}$ & $\mathrm{x}$ & $\mathrm{x}$ & & $\mathrm{x}$ & & $\mathrm{x}$ & $\mathrm{x}$ \\
\hline Energy & $\mathrm{x}$ & & $\mathrm{x}$ & $\mathrm{x}$ & $\mathrm{x}$ & & & & & & & \\
\hline Water and materials & & & & & & $\mathrm{x}$ & & & & & $\mathrm{x}$ & \\
\hline Economic impact & & & & & & & $\mathrm{x}$ & & & & & \\
\hline $\begin{array}{l}\text { Corporate investments/ } \\
\text { Investors/Creditors }\end{array}$ & & & & & & $\mathrm{x}$ & & & & & & \\
\hline Profitability/ Dividend & & & $\mathrm{x}$ & & & $\mathrm{x}$ & & & & & & \\
\hline Public sector & & & & & & $\mathrm{x}$ & & & & & & \\
\hline Stakeholder rights & & & & & & & & & & & $\mathrm{x}$ & \\
\hline Ethics & & & & & & $\mathrm{x}$ & $\mathrm{x}$ & $\mathrm{x}$ & & & & \\
\hline $\begin{array}{l}\text { Relationship with publics/ } \\
\text { External criteria }\end{array}$ & & & & & & & $\mathrm{x}$ & & & & & \\
\hline $\begin{array}{l}\text { Governance issues/ Good } \\
\text { business practices }\end{array}$ & & & $\mathrm{x}$ & $\mathrm{X}$ & 8 & & $\mathrm{x}$ & $\mathrm{X}$ & & & & \\
\hline
\end{tabular}

Our study focuses on corporate sustainability, since it is more comprehensive than corporate social responsibility (Steurer et al., 2005; Lozano, 2011), and it focuses not only on short-term but also long-term aspects of companies' activities (Bansal and DesJardine, 2014; Hahn et al., 2015). In our work, eight dimensions are used defined to cover the company's sustainability disclosure under TBL perspective. These disclosure dimensions are presented below, as well as some examples of the aspects that can be included in each of them:

- Products and services - include product quality and product safety (Tang et al., 2015), recyclable products and energy-efficient products (Raghupathi and Raghupathi, 2019);

- Economic action - include actions related to the economic impact of the enterprise (Capriotti and Moreno, 2007), profitability and other performance measures, dividend distributions (Sobhani et al., 2012; Ho and Taylor 2007), corporate investments (Ho and Taylor, 2007);

- Customers - include customer relationships, complaints/satisfaction, provision for disabled, aged, and difficult-to-reach customers (Branco and Rodrigues, 2006);

- Suppliers - include fair relations (Carvalho, 2013);

- Corporate governance and ethics - include transparency, organizational responsibility/government departments (Capriotti, and Moreno, 2007; Raghupathi and Raghupathi, 2019), ethical compromises (Capriotti, and Moreno, 2007; Ho and Taylor, 2007; Tagesson et al., 2009);

- Human resources (HR) - include employee health and safety (Van der Laan et al., 2005), employee welfare (Khün et al., 2018), education/training programs (Van der Laan et al., 2005; Branco and Rodrigues, 2006), employee development and equal opportunity for employees (Tang et al., 2015), compliance with labour rights (Khün et al., 2018), human rights such as children labour (Capriotti, and Moreno, 2007); 
- Environment - including recycling, pollution and waste management (Van der Laan et al., 2005; Ho and Taylor, 2007), resources conservation, e.g., water, energy (Van der Laan et al., 2005; Ho and Taylor, 2007), landscaping activities (Van der Laan et al., 2005);

- Community involvement - include education, sports, art, and culture (Van der Laan et al., 2005; Branco and Rodrigues, 2006), support of social programs (Van der Laan et al., 2005), plant site visitations (Van der Laan et al., 2005), poverty reduction, and public health (Tang et al., 2015).

\subsection{Sustainability disclosure of Portuguese companies}

There are few studies concerned with sustainability reporting in the Portuguese context. The existing studies use different approaches and focusing on different objectives. For example, Ferreira (2004), using an accounting perspective, has analyzed annual reports of 10 Portuguese companies considered representative of their industrial sectors. With this study, they try to know if the companies present environmental information, where that type of information is presented, what type, and how the information is disclosed. Branco and Rodrigues (2006) analyzed the social responsibility disclosure of 15 Portuguese banks and discussed the factors that influence the disclosure of this information. They seek to analyze to what extent banks use their websites as a medium to disclose social responsibility information and identify what type of information they disclose. In a subsequent study, that involves 49 Portuguese companies, the authors seek to analyze the factors that influence social responsibility disclosure (Branco and Rodrigues, 2008); they concluded that Portuguese companies attribute greater importance to annual reports as disclosure media than to the Internet.

Focusing only on the environmental dimension, Monteiro and Aibar-Guzmán (2010) studied 109 large companies operating in Portugal; they find out that the level of environmental information present in annual reports (financial statements) and disclosed during the period 2002-2004 is low, although the extent of environmental disclosure increased, as well as, the number of Portuguese companies that disclose environmental information. Ramos et al. (2013) carried out a questionnaire with 69 companies from different sectors of activity that are members of the World Business Council for Sustainable Development (WBCSD) - BCSD Portugal; they analyze the companies reporting practices (e.g., frequency of reporting, adoption of reporting guidelines, report format/platform). One of the main conclusions is that the reporting practices are mainly confined to larger companies; the six SMEs understudy show poor environmental management and environmental performance evaluation and sustainability reporting profile.

Gomes et al. (2015) provide a descriptive analysis of current practices in sustainability reporting by 87 Portuguese companies from different sectors of activity. The sustainability reports under analysis include both the autonomous reports and those integrated with the annual reporting. Ribeiro et al. (2016) studied the determinant factors affecting the degree of information disclosure of Portuguese municipalities; to this end, they analyzed the extent of online social responsibility information disclosure by those entities. More recently, Dias et al. (2019) have analyzed the disclosure of corporate social responsibility practices in 57 Portuguese companies of different sizes to understand whether business characteristics influence corporate social responsibility disclosure strategies. Considering the companies with certification in the different management systems, Carvalho et al. (2019) analyzed the nature of the content that is often disseminated on its corporate website regarding integrated management systems, environmental policy, corporate sustainability, and corporate social responsibility.

In a cross-country context, two studies compare the Portuguese companies' sustainability reporting practices with other countries. Anunciação et al. (2016) try to understand how top companies in Brazil and Portugal report sustainability practices through the analysis of their sustainability reports. Branco et al. (2018) based on the reports of the GRI database investigate the sustainability reporting practices of companies based in the Nordic countries (Denmark, Finland, Norway, and Sweden) and the Mediterranean European countries (Greece, Italy, Portugal, and Spain) for the period 2013-2015.

\section{Research questions}

To study the online sustainability disclosure of Portuguese mould companies a three-step research design was used. First, we would verify if the companies belonging to this sector provide on their websites documents related to sustainability. In a second step, and for the companies that disclose information related to sustainability, we would like to verify if company size is a factor that affects the amount of sustainability information disclosed. Finally, we want to know what type of sustainability-related information is disclosed by companies on their websites. The next paragraphs present the rationale behind this research design and the research questions that will guide the data collection procedure. 
In addition to an improved engagement with a broader range of stakeholders the Internet also makes it possible to use different formats of sustainability information (Amran et al., 2015). When compared with other conventional communication' channels (e.g., media), the Internet presents many advantages mainly in terms of form (text, still image, moving image, sound, interaction) which could be strategic for becoming the information disclosed about sustainability more appealing (Isenmann et al., 2007). The information disclosed on the company's website is usually disseminated using text or images or by providing access to a variety of corporate documents instead of formal reports such as sustainability reports or codes of conduct (Morhardt, 2010). Therefore, Chaudhri and Wang (2007) argue that how the website and the information are disclosed should be studied empirically. Several studies (Chaudhri and Wang, 2007; Dincer and Dincer, 2010; Branco et al., 2014) have analyzed the main formats used by companies to disclose information about sustainability and the way they provide documents related to sustainability. Being so, the first research question is formulated:

\section{$R Q_{1}$ : Do the Portuguese mould companies provide sustainability-related documents on corporate websites, and which are the main formats used?}

The literature has given importance to a set of determinants of sustainability disclosure. Among the vast quantity of determinants studied the "company size" has been one of the most studied in this field. For example, Bae et al. (2018) concluded that the company size has an insignificant relationship with online sustainability disclosure. Also, Tubai and DeLeon (2020) determined whether there is a significant difference in the content of website disclosure about the sustainability efforts of mining companies attending to their size. The variable company size was also adopted from Tagesson et al. (2009), who studied the determinants of social disclosures in corporate groups.

As can be seen, company size has been a determinant considered in several studies positively related to sustainability reporting and disclosure (Dienes et al., 2016). It is also argued that large companies have more resources to spend on sustainability practices and subsequently disclose more on such practices. Besides, Bae et al. (2018, p. 560) highlight that large companies, "are also subjected to more public scrutiny, the greater possibility of political attack and greater regulation, which force the companies to disclose more sustainability information. As such, larger companies tend to disclose more sustainability information as part of their strategy to maintain their leadership and to gain legitimacy from their primary stakeholders".

In Portugal, some studies have analyzed the influence of this variable on sustainability disclosure, such as Robalo and Patrocínio (2018). Not knowing, however, if there are differences in the Portuguese mould companies, which leads us to the following research question:

$R Q_{2}$ : Do the size of the Portuguese mould companies influences the amount of sustainability information disseminated on their websites?

To explore deeper this research question, the following hypothesis is suggested.

$H_{1}$ : There are significant differences in the amount of sustainability information disseminated on the Portuguese mould companies' websites attending to the company size.

In addition to the amount of information disclosed on company websites, the type of information disclosed may be significantly different. The voluntary nature of disclosure has been translated into a different extent of sustainability considerations (Hahn and Kühnen, 2013). Existing studies focus on different natures of the information related to sustainability (as can be seen in Table 1). Several studies show differences in the type of information disclosed, depending on the countries. By studying 32 Danish and Norwegian companies and 26 companies from the United States, Van der Laan et al. (2005) concluded that the most widely disseminated information in Danish and Norwegian companies are the environmental practices $(55 \%)$, followed by information on human resources $(26 \%)$. Environmental information (16\%) is less widely disseminated than information about the products and consumers $(26 \%)$ and information on philanthropy and social involvement (26\%). On the contrary, the information disclosed in the latter subjects is the Danish and Norwegian companies, representing only $7 \%$ and $2 \%$, respectively.

Moreover, Kühn et al. (2018), have analyzed the corporate websites of 211 companies from different sectors in seven sub-Saharan countries and conclude that of the three dimensions analyzed (community involvement, socially responsible production processes, and socially responsible employee relations) the focus is placed in the community involvement dimension on issues such as education and training (with a seven-country mean of $80 \%)$, health and disability (68\%), community development (63\%), the well-being of young people and children (62\%) as well as the environment (61\%). In the study conducted in Spanish and Swedish companies, Branco et al. (2014) verified that the Spanish companies disclose mainly information about social and philanthropic involvement, while the Swedish companies disseminate more information about the environment, human resources, or products and consumers. It seems thus that the 
type of information disclosed may differ from country to country and sector to sector (Kühn et al., 2018). As far as we know, there are no studies on the type of information disclosed in the moulds industry in Portugal. The type of information that is disclosed may reflect the importance given to the different issues related to sustainability (e.g., environmental, human resources, among others), which leads us to formulate the following research question:

\section{$R Q_{3}$ : What type of sustainability information do the Portuguese mould companies disclose on their websites?}

\section{RESEARCH METHODOLOGY}

\subsection{Research sample}

In this study, the mould industry was chosen as a research unit because the companies in this sector are expected to be subject to the pressures and requirements of sustainability by the various stakeholders and to respond to their pressures and demands, particularly in terms of disseminating information related to sustainability practices and performance (CEFAMOL, 2014). In 2017 the Portuguese mould industry was made up of approximately 740 companies. These companies are dedicated to the design, development, and manufacture of moulds and specialized tools, namely for plastics injection (CEFAMOL, 2014). There are several ways and criteria to define the dimension size of organizations (e.g., Van der Laan, 2005; Ramos et al., 2013). The classification criteria used in this study is the number of employees and turnover. According to the European Commission (EU, 2003), companies classified as SMEs have a turnover of fewer than 50 million euros and fewer than 250 employees. It is possible to distinguish between micro, small, and medium-sized enterprises, according to the recommendation previously mentioned. Ramos et al. (2013) also use this definition to analyze reporting in Portuguese large size companies and SMEs.

The initial sample was formed by the 100 top companies in the sector, according to the Portuguese Business Association (PBA, 2019). This sample contains the only large size Portuguese company in the mould industry company (The Simoldes company), in addition to 42 medium-size companies, 54 small companies, and 3 micro-companies. Considering that this study seeks to analyze the quantity and type of information available on the websites, in the first stage, it was verified which companies had an accessible website. All the companies whose websites were unavailable or non-existent (seven companies) were excluded from the sample.

In the case of companies belonging to business groups, we follow the same procedure as Chaudhri and Wang (2007) and Carvalho et al. (2018): it were included in the sample only the companies that made available a micro-website in the corporation' website, or when a specific section (page) related to the company. So, if the information was found only on the business group's website, companies were excluded from the sample. Based on this criterion, 10 companies were excluded. It is worthy to notice that because of this exclusion criterion, the single large size Portuguese mould company was excluded from the sample. The sampling process resulted in a sample of $83 \mathrm{SME}$, from a universe of 740 companies; it represents a sample rate of $11.22 \%$. Appendix A contains a list of companies that were included in the sample.

In what respects the motivations of companies to disclose information related to sustainability, it is necessary to notice that EU directive 2014/95 / EU, transposed into Portuguese law in 2017, states that companies (publicly listed companies, banks, insurance companies and companies designated by national authorities as public-interest entities), with at least 500 employees, must disclose non-financial information (e.g. regarding environmental protection, social responsibility, and treatment of employees, human rights). None of the 83 companies is covered by this or other legislation that requires disclosure information regarding their sustainability credentials. By law, Portuguese SMEs (excluding micro-entities) are only required to report financial information.

\subsection{Content analysis}

A content analysis methodology (Krippendorff, 2004) was used and applied to the corporate websites of the 83 companies. This approach is appropriate when an existing theory or previous research on a phenomenon is incomplete or benefits from a more detailed description (Hsieh and Shannon, 2005). Content analysis is primarily intended to provide an objective, systematic, and possibly quantitative description of the contents of the various types of communications (e.g., interviews, images, documents of a different nature) (Kassarjian, 2017). This methodology has been widely used to examine the content of companies 'communications (Sobhani et al., 2012). We can find content analysis in studies focusing on the dissemination of information on the environment, sustainability, and social responsibility based on reports whether on paper (e.g., Van der Laan et al., 2005) or in studies that analyze websites (e.g., Capriotti and 
Moreno, 2007; Joseph and Taplin, 2011; Tang et al., 2015; Kiliç, 2016). To perform the context analysis, we followed the methodological steps suggested by Mayring (2000) as described in the next subsections.

\subsubsection{Documentary Corpus}

After defining the theoretical framework and research questions, it is necessary to define the corpus of documents that will be subject to analysis. In this study, the corpus was defined as the set of information disclosed on the company website. Thus, for each company in the sample, it was decided to analyze all the pages of the company's website; this includes not only the information in a text format but also the documents available for download (usually in PDF).

\subsubsection{Definition of categories and units of analysis}

We follow a direct approach where the researcher is asked to read and classify the text in a previously defined category, but the possibility of identifying new categories from the collected data is not eliminated (Mayring, 2000). Nine data categories were established (Table 2): C1 -"Structure of the corporate website", C2 - "Manuals, codes and other corporate documents", C3 - "Reports and corporate statements", C4 "Certificates and corporate registrations", C5 - "Normative references, symbols, and corporate brands", C6 - "Corporate indexes", C7- "Corporate policies", C8 -"Corporate sustainability internal programs/ initiatives/practices internal" and C9- "Corporate sustainability programs/initiatives/practices of involvement with the community and other stakeholders". The last category intends to obtain data that shows the interaction/relationship of the companies not only with the community, for example taking philanthropy initiatives, but also other initiatives involving their supply chain partners (Seuring and Gold, 2013).

These nine categories have been deployed in 48 items to make the data collection work more objective. The items represent subjects under analysis and were established based on the set of disclosure information dimensions that result from the literature review (section 2.1) and in particular on the work of Carvalho et al. (2019), Carvalho et al. (2018), Joseph and Taplin (2011) and Capriotti and Moreno (2007). The terms and definitions used related to the items (e.g., sustainability reports, indicators, and sustainability indexes) followed the proposal of Carvalho et al. (2019).

An important decision when defining the categories is their mutual exclusivity (Weber, 1990). Categories must be independent of one another. In the event of item(s) that belong to more than one category, we followed the decision rule from Hackston and Milne (1996, p. 86): "If any sentence has more than one possible classification, the sentence should be classified as to the activity most emphasized in the sentence".

After defining the categories and items, the units of analysis were defined for each of the categories. The units of analysis can be a word, phrase, theme, or even documents in their integral form.

Table 2 - Categories, items, and units of analysis

\begin{tabular}{|c|c|c|}
\hline Categories of analysis & Items & $\begin{array}{l}\text { Units of analysis } \\
\text { (registration units) }\end{array}$ \\
\hline $\begin{array}{l}\text { C1- Structure of the } \\
\text { corporate website and format } \\
\text { of information }\end{array}$ & $\begin{array}{l}\text { 1. The website displays the theme of Corporate } \\
\text { Sustainability } \\
\text { 2. The website displays information through text and/or } \\
\text { images }\end{array}$ & $\begin{array}{l}\text { Pages } \\
\text { The theme }\end{array}$ \\
\hline $\begin{array}{l}\text { C2- Manuals, codes, and } \\
\text { other corporate documents }\end{array}$ & $\begin{array}{ll}\text { 3. } & \text { Quality manual } \\
\text { 4. } & \text { Environmental manual } \\
\text { 5. } & \text { Occupational health and safety manual } \\
\text { 6. } & \text { Human resources manual } \\
\text { 7. } & \text { Sustainability manual } \\
\text { 8. } & \text { Social responsibility manual } \\
\text { 9. } & \text { Code of good practices } \\
\text { 10. } & \text { List of environmental impacts and safety risks } \\
\text { 11. } & \text { Code of ethics and corporate conduct } \\
\text { 12. } & \text { Corruption risk management plan }\end{array}$ & The document \\
\hline $\begin{array}{l}\text { C3- Reports and corporate } \\
\text { statements }\end{array}$ & $\begin{array}{l}\text { 13. Sustainability report } \\
\text { 14. Social responsibility report } \\
\text { 15. Environmental report } \\
\text { 16. Occupational health and safety report }\end{array}$ & The document \\
\hline
\end{tabular}




\begin{tabular}{|c|c|c|}
\hline 20 & $\begin{array}{l}\text { 17. Annual report or corporate report } \\
\text { 18. Accounts report } \\
\text { 19. Financial report } \\
\text { 20. Corporate governance report } \\
\text { 21. Environmental statement or performance report }\end{array}$ & \\
\hline $\begin{array}{l}\text { C4- Certificates and } \\
\text { corporate registrations }\end{array}$ & $\begin{array}{l}\text { 22. Certificate of conformity QMS (ISO 9001) } \\
\text { 23. Certificate of conformity EMS (ISO 14001/ EMAS } \\
\text { III) } \\
\text { 24. Certificate of conformity OHSMS (OHSAS } \\
\text { 18001/ISO 45001/NP 4397) } \\
\text { 25. Certificate of conformity HRMS (NP 4427) } \\
\text { 26. Certificate of conformity SRMS (SA 8000/NP 4469) } \\
\text { 27. Other certificates and registers }\end{array}$ & The document \\
\hline $\begin{array}{l}\text { C5- Normative references, } \\
\text { symbols, and corporate } \\
\text { brands }\end{array}$ & $\begin{array}{l}\text { 28. } \text { Reference, symbol, or brand QMS (ISO 9001) } \\
\text { 29. Reference, symbol, or brand EMS (ISO 14001/ } \\
\text { EMAS III) } \\
\text { 30. Reference, symbol, or brand OHSMS (OHSAS } \\
\text { 18001/ ISO 45001/ NP4397) } \\
\text { 31. Reference, symbol, or brand HRMS (NP 4427) } \\
\text { 32. Reference, symbol, or brand SRMS (SA 8000/NP } \\
\text { 4469) } \\
\text { 33. Other references, symbol, or brand-related to CS }\end{array}$ & The word \\
\hline C6- Corporate indexes & $\begin{array}{l}\text { 34. Indicators and indexes about financial issues } \\
\text { 35. Indicators and indexes about Corporate } \\
\text { Sustainability issues }\end{array}$ & The theme \\
\hline C7- Corporate policies & $\begin{array}{ll}\text { 36. } & \text { Quality policy } \\
\text { 37. Environmental policy } \\
\text { 38. Occupational health and safety policy } \\
\text { 39. Human resources policy } \\
\text { 40. Sustainability policy } \\
\text { 41. Social responsibility policy }\end{array}$ & The theme \\
\hline
\end{tabular}

C8- Corporate sustainability internal programs/ initiatives/practices internal
42. Programs/initiatives/practices related to human resources (e.g., health and safety, employee welfare, employee development, equal opportunity for employees, human rights)

43. Programs/initiatives/practices related to the environment (e.g., to recycle, waste management)

The theme

44. Programs/initiatives/practices related to products and services (e.g., product quality and safety)

45. Corporate Governance and ethics (e.g., transparency)

46. Economic action (e.g., corporate investments)
C9- Corporate sustainability programs/initiatives/practices of involvement with the community and other stakeholders
47. Programs/initiatives/practices related to community involvement (e.g., philanthropy and social involvement)

48. Programs/initiatives/practices related to suppliers and customers (e.g., share information, technical support)

Note: EMAS - Eco-Management and Audit Scheme; QMS - Quality Management System; EMS - Environmental Management System; OHSMS - Occupational Health and Safety Management System; HRMS - Human Resources Management System; SRMS Social Responsibility Management System; ISO - International Organization for Standardization; OHSAS - Occupational Health and Safety Assessment Series; NP - Portuguese Standard; SA - Social Accountability.

In this study, the procedure suggested by Bosco (2017) to account for the disclosure occurrence of each category is used. Disclosure occurrence measures, not the number of times that the term was used, but only determining if the term was used, even once. The value of measurement can either be 0 if not used and 1 if used regardless of how many times it was used (Mayring, 2000). In this way, it is considered the "disclosure occurrence" and not the "disclosure abundance". These two concepts are quite different since the disclosure occurrence counts the number of disclosure items in the checklist that have been released (Joseph and Taplin, 2011).

\subsubsection{Data collection and quantification}


The set of measures taken to ensure data reliability is an important methodological issue in content analysis. Kaplan and Goldsen (1965) consider that the reliability of data is related to the ability of data to remain constant throughout variations in the measuring process. Also, Bolognesi et al. (2016) stress the importance of data reliability to assure that the same data is obtained independently of the measuring event, instrument, or person.

To assure data reliability a coding book was developed to support the research process (Appendix B). Nili et al. (2017) refers that when selection a method to calculate the inter-coder reliability in content analysis the type of data and the agreement level between two or more independent coders should be taken into consideration. In our research, we used only a nominal scale (i.e. "yes/no") to check if a category or item is present or absent in a website; also we used an interval scale to count the number of pages used by companies in their website to communicate sustainability-related information. Two native speakers of Portugal coded all the websites; this, was possible because of the sample size and the limited sustainabilityrelated information available in the company's website. In this way, any disagreement between coders was solved during the codding, when necessary the category and item was refined in the coding book.

Another issue that needs to be addressed is related to the quality of the researchers who perform the annotation and code the data need. Krippendorff (2014) points out that the researchers involved in the content analysis should be experts in the field under study. Moreover, the researchers who code the data should ideally not be the same people who constructed the categories. This distinction is necessary because two (or more) researchers who worked together to develop a coding scheme and engaged in discussions that led to mutual clarifications and agreements on the same perspectives will often generate a higher score in intercoder agreement than a fresh set of coders. Following these premises, the methodology used in this work to register the level of disclosure of information on corporate sustainability present in the websites was assessed by three researchers. One researcher worked on defining the categories to analyze the websites and the other two were responsible for the data coding.

The data collection was carried out between February and March 2019. The information-gathering process was carried out through the observation and direct analysis of the companies' websites, based on the defined categories and items. To register the data, a check matrix was elaborated, where the "presence" or "absence" of information disclosed was recorded.

To respond to RQ1 research, which is related to how information is presented, the analysis of sustainabilityrelated documents provided data related to the categories: C2 -"Manuals, codes, and other corporate documents", C3 - "Reports and corporate statements", C4 - "Certificates and corporate registrations", C5"Normative references, symbols, and corporate brands", C7 - "Corporate policies". The presence of documents (manuals, reports, certificates, documents with company policies, among others) was also verified; when presented in PDF, it was downloaded and analyzed. We follow Carvalho et al. $(2018,2019)$ when considering the certificates and registrations, as we understand that these can be used as a way for companies to evidence and communicate their commitment to sustainability in different dimensions (e.g., environmental, health, and safety of workers).

In visual communication, it was analyzed the resources used by companies: photos, videos, and the presence of references/symbols associated with the certification of management systems (e.g., Social Responsibility Management System) (Carvalho, et al. 2019). Due to the difficulty in objectively determining the purpose of the images (Van der Laan et al., 2005), the following rule was defined: these elements are associated with sustainability only if they do not raise any doubts of interpretation or are subtitled or inserted in pages or sections related to sustainability.

In order to answer the RQ2 and to analyze the amount of sustainability information disseminated on companies' websites, the number of web pages where this kind of information is disclosed was used as the unit of analysis. There is an ongoing debate on the most appropriate unit of analysis for studies that employ content analysis (Van der Laan et al., 2005). In this work, we follow previous studies that use the number of pages as a criterion to assess the extent of disclosure on corporate websites (e.g., Chaudhri and Wang, 2007; Dincer and Dincer, 2010; Kühn et al. (2018). As stated by Chaudhri and Wang (2007, p.239), "Although the number of pages by itself is not an accurate reflection of corporate commitment to social responsibility, it attests to the amount of effort invested by a company to communicate its commitment".

Kühn et al. (2018) also consider that the number of pages represents an indicator of the degree of attention paid to sustainability reporting. We also follow the categories proposed by some of these studies (e.g., Kühn et al. 2018; Chaudhri and Wang, 2007) which reflect the greater or lesser extent of reporting by using the following scale: minimal sustainability reporting (one to two pages), medium sustainability reporting (three to 10 pages), and extensive sustainability reporting (more than 10 pages). 
To analyze if there are differences in the amount of sustainability information disclosed by companies' size and the Kruskal-Wallis non-parametric test will be used. This test was used since data distribution is not normal.

To obtain the type of information disclosed in the websites, and to answer the research question $\mathrm{RQ}_{3}$, the data were collected based on categories C6- "Corporate indexes", C8- "Corporate sustainability internal programs/ initiatives/practices internal", and C9 - "Corporate sustainability programs/initiatives/practices of involvement with the community and other stakeholders". Some studies (e.g., Van der Laan et al., 2005) have analyzed the type of information disclosed based on the sentence count and page count by type of disclosure. Our objective was not to analyze how often the themes were mentioned, but the type, the nature of the information disclosed. Although one of the main limitations of this type of analysis is not to reflect the emphasis that companies associated with each information item, the number of different topics analyzed can be considered a reasonable measure of management's willingness to provide sustainability information in general (Branco and Rodrigues, 2008). Therefore, it was analyzed for each company if the theme was mentioned or not on the website.

\section{RESULTS AND DISCUSSION}

\subsection{Quantity and nature of the sustainability-related information disclosed}

The sample analysis provides evidence that the majority of companies in the mould industry disclose in their websites information related to sustainability. It should be noticed that only one company in the selected sample do not disclose any information related to sustainability. Companies that disclose information about sustainability seem to have a strong predisposition to disseminate information almost exclusively through text (Table 3 ).

Table 3 - Presence of sustainability information disclosed on corporate websites

\begin{tabular}{lcc}
\hline Sample size & Number & $\mathbf{\%}$ \\
\hline C1 - "Sustainability disclosed on the website" & 83 & \\
Organizations that disclose sustainability information & 82 & $98.80 \%$ \\
Organizations that do not disclose sustainability information & 1 & $1.20 \%$ \\
Format of information & & \\
$\quad$ Text and images & 10 & $12.20 \%$ \\
Text & 72 & $87.80 \%$ \\
$\quad$ Images & 0 & $0.00 \%$ \\
Documents & 0 & \\
C2 - "Manuals, codes and other corporate documents" & 2 & $0.00 \%$ \\
C3 - "Reports and corporate statements" & 2 & $2.44 \%$ \\
Annual report or corporate report & 33 & $40.24 \%$ \\
C4 - "Certificates and corporate registrations" & 16 & $19.52 \%$ \\
Certificate of conformity QMS (ISO 9001) & 2 & $2.44 \%$ \\
Certificate of conformity EMS (ISO 14001) & 3 & $2.46 \%$ \\
Certificate of conformity OHSMS (OHSAS 18001) & 12 & $14.64 \%$ \\
Other certificates and registers & & \\
\hline
\end{tabular}

Only 10 companies (12.20\%) present information complemented by images (or pictures). This result is aligned with previous studies about this issue. Robalo and Patrocínio (2018) also note that foundations 'type organizations prefer using text in the disclosure of corporate information, but in what is related to the dissemination of sustainability those organizations choose to present text and image. Some of the examples of images found include pictures of or past and ongoing initiatives, such as non-smoking campaigns, scholarship grants, or reforestation campaigns. Chaudhri and Wang (2007) also verified the existence of images related to different sustainability initiatives (e.g., computer lessons in session, blood donation camps). In their study, two groups of companies (local and global) were analyzed, and local companies tend to favor text. Similar in our study, in which the type of companies analyzed falls within the classification of local companies (attending to the Chaudhri and Wang (2007) criteria), most companies communicate sustainability in their webpage by using text.

The results indicate that only two companies present their corporate (management) reports. None of the other documents listed in categories C3 - "Manuals, codes, and other corporate documents" and C4 - 
"Reports and corporate statements" are disclosed. In the case of C7 - "Corporate policies", 19 companies present only their quality policy and their environmental policy, not in a separate document but within the content of a page or section. These results are not aligned with previous studies in Portuguese organizations. Carvalho (2013) found that the most publicized documents by Portuguese certified companies are in descending order: "Report and Accounts", "Code of Ethics and Business Conduct", and "Sustainability Report". According to Robalo and Patrocínio (2018), "Codes of Conduct" are also a type of document widely disseminated by the Portuguese foundation' type organizations, since most of them disclose codes of conduct, but as far as sustainability reports are concerned, they are only disclosed by a minority of those organizations.

Regarding the documents as sustainability reports, the companies studied do not present any report related to sustainability, or even to their environmental and social dimensions. Other studies also refer to the poor disclosure of such documents. For example, Chaudhri and Wang (2007) find only one company that presents its corporate social responsibility report on its website; Dincer and Dincer (2010) register two companies with an annual report that provides detailed information on corporate social responsibility projects. Considering the trend towards the publication of stand-alone sustainability or sustainability/ corporate social responsibility report (Fifka, 2012) would expect companies to disclose this type of documents, which does not happen.

It is noted, however, that these companies seem to give some importance to the presentation of certificates attesting their management systems following international standards, C5- "Certificates and corporate registrations". Certification is a way for stakeholders to assess the commitment and performance of companies concerning their activity and practices/initiatives and for companies to achieve legitimacy and reputation. In the sample analyzed, these certificates are mostly associated with the economic dimension of sustainability: 16 companies present in the website the ISO 9001 certificate; only two from the seven companies that report having their environmental management system certification (ISO 14001) present the certificate, and from the seven companies that claim to have the certification of their Occupational Health and Safety Management System (OHSAS 18001) only three present their certificate. There is also a relatively high number of companies (12) that present other types of certificates: four companies have the ISO/TS 16949 certificate (Quality management system for the automotive sector), seven companies have the Management System of Research certification, Development and Innovation (NP 4457) and one company own the certification of the energy management system (ISO 50001: 2011). It seems that the focus of the mould industry on innovation and technical and technological aspects is reflected in terms of certification options and consequently, the type of documents disclosed (e.g., the presence of certificates) on their websites.

\subsection{Website sustainability disclosure of different size companies}

As regards the influence of the company size on the amount of sustainability information disseminated on their websites, the number of pages dedicated to the sustainability disclosure was registered for each company. The data was then organized in Table 4, showing that none of the companies in the sample dedicates more than 10 pages of their website to the sustainability disclosure. As can be seen in Table 4, our sample is made up mostly of small companies: from the 82 companies that disclosed sustainability information, 47 companies are small, 32 are medium-sized, and there are also three micro-enterprises. Attending to Table 4, we found that $59.57 \%$ of the small companies present mainly information on sustainability in one or two pages, indicating a minimum level of reporting on their websites. In the medium-size companies' group, the results show that $50 \%$ of the companies dedicate one or two pages of their website to sustainability disclosure; the remaining 50\% medium size companies dedicate until 10 pages.

Table 4 - Sustainability information disclosed on corporate websites according to the company size

\begin{tabular}{ccccc}
\hline & $\mathbf{N .}^{\circ}$ companies & \multicolumn{3}{c}{ Company size } \\
\hline $\begin{array}{c}\mathbf{N .}^{\mathbf{0}} \text { pages dedicated to } \\
\text { sustainability }\end{array}$ & 82 & $\begin{array}{c}\text { Micro } \\
(3 \text { companies })\end{array}$ & $\begin{array}{c}\text { Small } \\
(47 \text { companies })\end{array}$ & $\begin{array}{c}\text { Medium } \\
\text { (32 companies) }\end{array}$ \\
\hline Minimal (1-2) & 47 & 3 & 28 & 16 \\
& $(57.32 \%)$ & $(100 \%)$ & $(59.57 \%)$ & $(50.00 \%)$ \\
\hline Medium (3-10) & 35 & 0 & 19 & 16 \\
$(42.68 \%)$ & $0.43 \%)$ & $(50.00 \%)$ \\
\hline Extensive (+10) & 0 & 0 & 0 & 0 \\
\hline
\end{tabular}


Note: i) medium-sized companies: number of employees (50-249) and turnover < EUR 50 million; ii) small companies: number of employees (10-49 and turnover < EUR 10 million; iii) micro-companies: number of employees ( $<10$ employees), and turnover $<$ EUR 2 million.

To explore these results deeply and to answer $\mathrm{RQ}_{2}, \mathrm{H}_{1}$ was tested using the Kruskal-Wallis non-parametric test (Table 5). Attending to Table 5 we can state that there is not a statistically significant difference in the amount of sustainability information disseminated on the Portuguese mould companies' websites attending to the company size. Being so, the $\mathrm{H}_{1}$ is not verified. These results do not support the existing studies such as Van der Laan et al. (2005) and Bae et al. (2018), who argue that larger companies tend to disclose more information on sustainability.

Table 5 - Kruskal-Wallis test for company size $\left(\mathrm{H}_{1}\right)$

\begin{tabular}{ll}
\multicolumn{2}{c}{ Test statistics $\mathrm{a}, \mathrm{b}$} \\
\cline { 2 - 2 } Chi-Square & 3.614 \\
df & 2 \\
Asymp. Sig. $\quad 0,164$ \\
\hline a. $\quad$ Kruskal Wallis Test \\
b. $\quad$ Grouping Variables: Company Size
\end{tabular}

\subsection{Type of sustainability-related information disclosed}

To identify the type of information disclosed and to answer to RQ3, for each company, it was analyzed if in the website it is mentioned or not one of the following categories: C6- "Corporate indexes", C8"Corporate sustainability internal programs/initiatives/practices internal", and C9- "Corporate sustainability programs/initiatives/practices of involvement with the community and other stakeholders". The results are presented in Table 6, which organized the data retrieved from the sample along the eight sustainability disclosure dimensions proposed in section 2.1. Moreover, some examples of the information disclosed in the company's website are provided for a better explanation.

More than half of the companies $(57.32 \%)$ provide information related to their "Economic action" by emphasizing their investments in equipment, processes innovation and I\&D activities, or else by revealing their certificates and quality management systems. There is a need for mould companies to investing in advanced and innovative technologies so they can respond to the market demand for the prototypes development and short production series (which should be produced and delivered in very short periods of time). In particular, for mould companies, the ISO 9001 certification can be a requirement so they can be qualified as a supplier for major automakers. In our sample, $42.68 \%$ of the companies disclose information related to the dimensions "Products and Services" and "Customers". This could be justified because of the high competitiveness in the mould industry and the consequent need of Portuguese mould companies to assure high levels of service and product quality, as well as the development of mechanisms to collaborate with their customers. Also, the Portuguese mould companies would like to maintain their "good reputation" for product quality and competitive prices. The other dimension that seems to have more considerable attention on the part of the companies (35.36\%) is "Human resources", mainly focus employee training, health and safety and participation. This can be explained because of the need to assure talent retaining within their organizations, not only just for managerial functions, but also engineering and technical functions. In what is related to the sustainability dimensions "Environment", "Corporate governance", "Suppliers" and "Community involvement" most of the companies in the sample do not disclose any sustainability-related information. 
Table 6. Sustainability disclosure dimensions present in the sample.

\begin{tabular}{|c|c|c|c|c|}
\hline $\begin{array}{l}\text { Disclosure } \\
\text { dimension }\end{array}$ & Disclosed topics & Examples of evidence found in the sample* & $N^{o}$ companies & $\%$ \\
\hline $\begin{array}{l}\text { Economic } \\
\text { action }\end{array}$ & $\begin{array}{l}\text { Programs/initiatives/practices related } \\
\text { to Economic action (e.g., C8, item. } 46 \\
\text { - corporate investments) }\end{array}$ & $\begin{array}{l}\text { Types of major tangible investments: updating and renewal of productive equipment; reinforcing technologies and } \\
\text { methodologies - [ COM61] "To promote continuous improvement of ... manufacturing and control processes"; [ COM57] } \\
\text { "Implementation of new technologies for the development and optimization of processes in order to generate an increase in } \\
\text { productivity and income" }\end{array}$ & 47 & $57.32 \%$ \\
\hline $\begin{array}{l}\text { Products and } \\
\text { services }\end{array}$ & $\begin{array}{l}\text { Programs/initiatives/practices related } \\
\text { to products and services (e.g., C8, } \\
\text { item. } 44 \text { - product quality and safety) }\end{array}$ & $\begin{array}{l}\text { Product quality - [ COM61] "invest in the permanent updating of production equipment in order to keep up with } \\
\text { technological developments, reduce lead times and costs and improve the quality of the moulds produced"; [ COM47] "It is } \\
\text { our policy to ensure product compliance" }\end{array}$ & 35 & $42.68 \%$ \\
\hline Customers & $\begin{array}{l}\text { Programs/initiatives/practices related } \\
\text { to suppliers and customers (e.g., C } 8, \\
\text { item. } 48 \text { - share information, technical } \\
\text { support) }\end{array}$ & $\begin{array}{l}\text { Customer complaints/satisfaction_[ COM30] "Our goal is to fulfil our clients' requirements and increase their } \\
\text { satisfaction"; } \\
\text { [COM35] "is our strategic orientation:- customer satisfaction by ensuring the conformity of the agreed requirements, } \\
\text { proposing product improvements, promoting a partnership relationship"; [ COM77] "Promotes the continuous search for } \\
\text { total customer satisfaction"; [ COM64] "Our quality policy is based on customer satisfaction with a constant focus on } \\
\text { innovation / new areas of activity, new technologies" } \\
\text { Mechanisms to improve knowledge of needs and expectations__ [ COM20] "we develop a constant dialogue with our } \\
\text { customers, in order to know and anticipate their needs" }\end{array}$ & 35 & $42.68 \%$ \\
\hline $\begin{array}{l}\text { Human } \\
\text { resources }\end{array}$ & $\begin{array}{l}\text { Programs/initiatives/practices related } \\
\text { to human resources (e.g., C } 8 \text {, item. } 42 \\
\text { - health and safety, employee welfare, } \\
\text { employee development, equal } \\
\text { opportunity for employees, human } \\
\text { rights) }\end{array}$ & $\begin{array}{l}\text { Employee development - [ COM65] "promote the continuous development of all employees, encouraging the capacity for } \\
\text { initiative, promoting teamwork..." } \\
\text { Health and safety - [ COM44] "ensures and promotes (...) health and safety and promotes the involvement of employees and } \\
\text { all parties involved in health and safety management"; } \\
\text { [ COM44] "encourages its employees to stop smoking. Support its employees with the "No Smoking" campaign" } \\
\text { Risk Assessment in Occupational Safety and Health - [ COM15] "Identify and evaluate the main hazards, in order to define } \\
\text { actions to mitigate the risks to which workers are exposed and provision of appropriate safety equipment" } \\
\text { Employee participation - [ COM30] seeks "to value the participation and awareness of its employees...to improve its } \\
\text { performance and satisfaction" }\end{array}$ & 29 & $35.36 \%$ \\
\hline Environment & $\begin{array}{l}\text { Programs/initiatives/practices related } \\
\text { to the environment (e.g., C } 8, \text { item. } 43 \text { - } \\
\text { to recycle, waste management) }\end{array}$ & $\begin{array}{l}\text { Environmental pollution prevention - [ COM35] "has a strategic orientation environment protection by minimizing the } \\
\text { environmental impact and preventing pollution"; [ COM40] " } \\
\text { we are committed to carrying out our activities, directing them towards the protection of the environment, including the } \\
\text { prevention of pollution, through the rational use of natural resources and minimization of waste" } \\
\text { Conservation of natural resources (Waste Management) - [ COM44] "we are committed to being environmentally } \\
\text { responsible by preventing pollution of the environment, through the sustainable and rational use of natural resources and waste } \\
\text { management"; [ COM40] protect the environment "through the rational use of natural resources and minimization of waste" }\end{array}$ & 14 & $17.07 \%$ \\
\hline $\begin{array}{l}\text { Corporate } \\
\text { governance }\end{array}$ & $\begin{array}{l}\text { Corporate Governance and ethics (e.g., } \\
\text { C8, item. } 45 \text { - transparency) }\end{array}$ & Ethics - [ COM67] "Our conduct reflects good ethical standards regarding the environment and the safety of stakeholders" & 9 & $10.98 \%$ \\
\hline Suppliers & $\begin{array}{l}\text { Programs/initiatives/practices related } \\
\text { to suppliers and customers (e.g., C } 8 \text {, } \\
\text { item. } 48 \text { - share information, technical } \\
\text { support) }\end{array}$ & $\begin{array}{l}\text { Develop relationships to ensure the conformity of the agreed requirements, and reduce costs - [COM35] "It is a strategic } \\
\text { orientation the supplier involvement by promoting a partnership relationship and developing solutions to reduce costs"; [ } \\
\text { COM5] "Deepen the relationship with the usual suppliers in order to guarantee the fulfilment of the delivery deadlines } \\
\text { according to the applicable specifications" } \\
\text { Collaboration for continuous improvement of methods, processes, and products - [ COM69] "Cooperate with your } \\
\text { Suppliers by providing knowledge and information in an attempt to achieve mutual growth" }\end{array}$ & 7 & $8.54 \%$ \\
\hline $\begin{array}{l}\text { Community } \\
\text { involvement }\end{array}$ & $\begin{array}{l}\text { Programs/initiatives/practices related } \\
\text { to community involvement (e.g., C } 8 \text {, }\end{array}$ & $\begin{array}{l}\text { Support for education - [ COM81] "ensures tuition fees to the best student who enters the Mechanical Engineering course at } \\
\text { the Polytechnic Institute of Leiria" }\end{array}$ & 6 & \% \\
\hline
\end{tabular}


$\begin{array}{ll}\text { item. 47- philanthropy and social } & \text { Sponsoring sporting or recreational projects - [ COM81] "support local motocross team and local Club (Marinha Grande } \\ \text { Club) Roller Hockey "“. [ COM67] "promoted the district Championship of Cross Country" }\end{array}$ involvement)

Club) Roller Hockey "; [ COM67] "promoted the district Championship of Cross Country"
Support social institutions, as well as public interest initiatives - [ COM35] "financially supported national and

international causes" such as Public utility institutions for social solidarity, Public utility institutions for the development and

N. ${ }^{\circ}$ companies in the sample that disclose sustainability-related information

Note: * under brackets is the company code according to appendix A 
To characterize the online sustainability disclosure, during the data collection it was verified in each company website if there was information related to each one of the items belonging to categories C6"Corporate indexes", C8- "Corporate sustainability internal programs/ initiatives/practices internal", and C9 - "Corporate sustainability programs/initiatives/practices of involvement with the community and other stakeholders". Table 7 gathers this data organized by the sustainability disclosure dimension and classified according to the TBL perspective (economic, environmental, and social performance).

Table 7. Type of sustainability-related information disclosed by companies in the sample.

\begin{tabular}{|c|c|c|c|c|c|}
\hline Disclosure dimension & $\begin{array}{l}\text { N. }{ }^{\circ} \\
\text { comp. }\end{array}$ & TBL & Disclosure dimension & $\begin{array}{c}\text { N. }{ }^{\circ} \\
\text { comp. }\end{array}$ &.$^{\mathrm{TBL}}$ \\
\hline Environmental & & & Community involvement & & \\
\hline $\begin{array}{l}\text { Env/ policies or company concern for the } \\
\text { environment }\end{array}$ & 12 & $\boldsymbol{\Delta}$ & Support for solidarity campaigns & 3 & • \\
\hline Env/management systems and audit & 7 & $\boldsymbol{\Delta}$ & $\begin{array}{l}\text { Support social institutions, as well as public } \\
\text { interest initiatives }\end{array}$ & 2 & $\bullet$ \\
\hline Env/pollution prevention & 7 & $\boldsymbol{\Delta}$ & Charitable donations and activities & 1 & $\bullet$ \\
\hline $\begin{array}{l}\text { Conservation of natural resources (water } \\
\text { and energy) }\end{array}$ & 6 & $\boldsymbol{\Delta}$ & Sponsoring sporting or recreational projects & 1 & $\bullet$ \\
\hline Waste management & 4 & $\boldsymbol{\Delta}$ & Support for education & 1 & $\bullet$ \\
\hline $\begin{array}{l}\text { Conservation of energy in the condu } \\
\text { business operations }\end{array}$ & 3 & $\boldsymbol{\Delta}$ & $\begin{array}{l}\text { Collaboration in technological/ } \\
\text { research projects with universities and industry } \\
\text { associations }\end{array}$ & 1 & $\bullet$ \\
\hline Use of cleaner technologies & 1 & $\boldsymbol{\Delta}$ & Corporate governance and ethics & & \\
\hline $\begin{array}{l}\text { Compliance with applicable legal } \\
\text { requirements }\end{array}$ & 1 & $\boldsymbol{\Delta}$ & Ethics & 5 & $\bullet$ \\
\hline $\begin{array}{l}\text { Identification, assessment, and mitigation } \\
\text { of negative env/impacts }\end{array}$ & 1 & $\boldsymbol{\Delta}$ & Transparency & 4 & $\bullet$ \\
\hline Human resources & & & Customers & & \\
\hline Employee training & 18 & $\bullet$ & Customer complaints/satisfaction & 26 & - \\
\hline Employee participation & 13 & $\bullet$ & $\begin{array}{l}\text { Mechanisms to improve knowledge of needs and } \\
\text { expectations }\end{array}$ & 7 & घ \\
\hline $\begin{array}{l}\text { Employee H\&S policies or company } \\
\text { concern for } H \& S\end{array}$ & 10 & $\bullet$ & $\begin{array}{l}\text { Collaboration for continuous improvement of } \\
\text { methods, processes, and products }\end{array}$ & 5 & - \\
\hline Promoting professional development & 10 & $\bullet$ & Collaboration for the development of society & 2 & $\bullet$ \\
\hline Improving the working conditions & 3 & $\bullet$ & Collaboration in the development of new & $?$ & \\
\hline Employee morale & 3 & $\bullet$ & products & 2 & 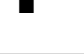 \\
\hline Adequate safety equipment & 1 & $\bullet$ & Suppliers & & \\
\hline Occupational H\&S Management System & 1 & $\bullet$ & $\begin{array}{l}\text { Develop relationships to ensure the conformity } \\
\text { of the agreed requirements, and reduce costs }\end{array}$ & 7 & - \\
\hline Risk Assessment in Occupational H\&S & 1 & $\bullet$ & $\begin{array}{l}\text { Collaboration for continuous improvement of } \\
\text { methods, processes, and products }\end{array}$ & 5 & घ \\
\hline & & & Collaboration for the development of society & 2 & घ \\
\hline Products and services & & & Economic action & & \\
\hline Product quality & 34 & $\mathbf{\square}$ & $\begin{array}{l}\text { Types of major tangible investments: updating } \\
\text { and renewal of productive equipment; } \\
\text { reinforcing technologies and methodologies }\end{array}$ & 9 & - \\
\hline Product safety & 1 & $\bullet$ & $\begin{array}{l}\text { R\&D investments } \\
\text { Quality management systems }\end{array}$ & $\begin{array}{c}5 \\
47\end{array}$ & ! \\
\hline
\end{tabular}

Note: $\boldsymbol{\Delta}$ - Environmental; •-Social; $\mathbf{\square}$ - Economic

It should be noticed a major difference between Table 6 and Table 7: in the first one, we find the number of companies in sample that, for each sustainability disclosure dimension, communicate information at least one time; in the second one, we find the number of companies that disclosure information for each item. Therefore, in Table 7 we can have more than one entry for each company; this provides an indication of the diversity of information that companies use to communicate sustainability in their websites. For example, in Table 6 we find that the information related to the dimension "Community involvement" is disclosed by six research companies. From the evidence column, we find that company labelled by "[COM81]" disclose information related with two items "Sponsoring sporting or recreational projects" and "Support for education". These two items appear in Table 7. 
From Table 7, it is possible to conclude that there is a higher diversity in the disclosure of information related to the economic perspective of the TBL. Also, the companies under analysis made some effort to communicate their initiatives related to the social perspective, namely in what is concerned with their human resources and community involvement.

Concluding, and to answer to RQ3, we find out that the Portuguese mould companies mainly communicate information related with "Economic action", "Products and Services", "Customers" and "Human resources" in an economic perspective.

The results obtained are aligned with the existing literature. A higher level of disclosure information related to products, customers and human resources more than community involvement and the environment was also observed by Kiliç (2016). Capriotti and Moreno (2007) stress that issues such as the general characteristics of the company (corporate profile) and its products and services being the more present and highlighted in the corporate websites, reinforces the idea of the self-presentation function of corporate websites. Reduced information at the environmental level was also found by Robalo and Patrocínio (2018). There may be differences in the type of information disclosed according to the type of company analyzed. In this sense, Hahn and Kühnen (2013) consider that the company's sector affiliation is the most frequently addressed external determinant of sustainability reporting. According to Tagesson et al. (2009), companies within the raw materials industry, or operating in "polluting sectors" such as the mining, oil and chemical industries), tend to emphasize information regarding environmental, health and safety issues, since they are essential issues in this industry. On another way, companies in the finance and service industries generally seem to report more on social issues and philanthropic deeds (Tagesson et al., 2009). Although the mould companies do not belong to the raw materials industry but to the manufacturing industry, it seems that environmental issues do not deserve much attention from the company's communication. Besides, mould companies supply their products to other companies and not directly to final consumers, which, according to Haddock-Fraser and Fraser (2008) may justify that environmental aspects are less communicated than close-to-market companies.

On the other hand, the choice of medium for information disclosure is dependent on the public target for whom the message is intended. According to Branco and Rodrigues (2006), as websites target a broader audience (e.g., customers) than other reporting media (e.g., annual reports directed to investors), it is natural for companies to highlight products/customers and even community involvement. However, while mould companies seem to focus on product and customer information predominantly, as mentioned above, this is not the case for information related to community involvement. The reduced attention to this aspect is also an element present in the results obtained by Van der Laan et al. (2005) based on annual reports of companies from the electric power generation and distribution industry. According to Tang and Li (2009), this may be related to the market's proximity. Close-to-Market companies seem to be more active in communicating their societal engagement like support for education or sponsorship (Tang and Li, 2009).

\section{CONCLUSIONS}

This paper aims to examine the quantity and nature of the content of the information related to sustainability that Portuguese moulds companies from different sizes communicate on their websites. A sample composed of 83 SME companies, was defined and the respective websites were analysed in detail using content analysis. The results show that just one company in the sample do not communicate any sustainabilityrelated information on its website. However, most companies in the sample present mainly information on sustainability in one or two pages, indicating a minimum level of reporting on their websites. The data obtained do not support a statistically significant difference in the amount of sustainability information disseminated on the Portuguese mould companies' websites attending to the company size.

About the type of information disclosed, considering the TBL (economic, social, environmental perspectives), the information involving environmental and social perspective is scarce. The focus is on aspects related to the economic dimension, particularly in the areas related to products and services and customers. Thus, the information disclosure approach seems to have a more commercial perspective, than a perspective that seeks to allow its various stakeholders an evaluation of the company's commitments to sustainability involving its various dimensions.

The limited information on sustainability disclosed verified in the mould companies is against some works that argue that recent policy changes have contributed to increasing pressures on companies to strengthen their sustainability communication (Truant et al., 2017), and sustainability disclosure has an increasing presence in corporate communication, from annual reports to websites (Sobhani et al., 2012). This can also 
be a signal that the mould industry is not so transparent as should be since sustainability disclosure contributes to reducing information asymmetry (i.e., increases transparency) for stakeholders by providing additional information.

We cannot conclude from the results that most companies in the mould industry do not develop efforts and actions to achieve sustainability since the results of the study are based on what companies choose to communicate. However, there seems to be a lack of proactivity to communicate these efforts and initiatives through the websites. This is contrary to the growing trend of using the Internet for disclosure information regarding sustainability issues (Hahn and Kühnen, 2013; Reilly and Larya, 2018). Thus, companies are not getting the advantages of sustainability disclosure, such as gains in legitimacy, improvement of relationships with stakeholders (Bae et al., 2018) and effectively lead or respond to widening stakeholder influence (Chaudhri and Wang, 2007).

According to Gray et al. (2001), the company must define, consult and engage its stakeholders in its sustainability programs to ensure that its activity is seen as relevant both to the business and to its stakeholders. In light of the stakeholder theory, the disclosure of sustainability information is a way of companies legitimates their behaviours since the legitimacy of an organization's behaviour is one of the cornerstones upon which its survival and development within society are founded (Scott, 1995). If society considers that the behaviour of organizations is undesirable or inappropriate, those organizations run the risk of disappearing (Suchman, 1995). Thus, if (as Stakeholder Theory maintains) company behaviour responds to the satisfaction of stakeholder demands (like the adopting of a sustainable behaviour), then according to Mitchell et al. (1997), companies will have incentives to attend to those demands that society considers legitimate. So, it is important to disclose sustainability information of companies to stakeholders could be informed and could legitimate or not their practices and also improve branding and image; and, to strengthen dialogue with stakeholders who are critical to their business.

It should be noted that the methodology used, although it has been followed in other investigations (Kühn et al., 2018), it can be considered as a limitation of our study. On the one hand, to improve their image with their stakeholders, companies can report and disseminate initiatives/practices that they do not. On the other hand, companies can carry out activities that they do not divulge, namely because of a lack of means or knowledge (Kühn et al., 2018). Also, the type of information disclosed may differ according to the means of dissemination used (Branco and Rodrigues, 2008; Bosco, 2017). Thus, new investigations using other dissemination tools (such as annual reports, nonfinancial reports, and other communication media), and even other research methodologies such as case studies, may provide a deeper understanding of the concerns and initiatives/practices of sustainability of mould companies. Moreover, although the companies under study have some common characteristics (e.g. size, activity, position in the supply chain) they can adopt different policies, strategies and practices in relation to the disclosure of sustainability information (Mura et al., 2019). Future studies may explore the organizational motivations/drivers that can affect the disclosure of sustainability information.

Despite these limitations, our study contributes to the knowledge of sustainability communication practices in SMEs, an area of research that needs to be more explored (Fifka, 2012; Mura et al., 2019) and in an industry (moulds) that have not received much attention in this area. Although SMEs have very strong social importance and impact in the global and economy (Dias et al., 2019), research on corporate sustainability has focused on large companies, with corporate sustainability in SMEs companies comparatively a less researched area (Das et al., 2020). With regard to corporate sustainability communication, the literature highlights that SMEs often lack in communicating their activities (e.g. social and environmental) in the scope of corporate sustainability to their stakeholders (Das et al., 2020). This study contributes to the literature on corporate sustainability communication in SMEs, increasing knowledge about the type and extent of corporate sustainability activities developed and reported by this type of companies and in a specific industry (moulds) that have not received much attention in this area. Thus, the authors believe that this study can also be a stimulus for future research in sectors that have been little studied.

Moreover, this study by providing the state-of-the-art of the online sustainability disclosure of companies contributes to tracking the progress towards the achievement of the 17 SDS goals of the 2030 Agenda for Sustainable Development (Tsalis et al., 2020). The conclusions of this study make possible to confirm also whether the rising interest in sustainability reporting, not only from governments but also from investors and stock exchanges, by creating regulatory instruments and incentives for reporting has encouraged the disclosure of sustainability information (Shoaf et al., 2018). 


\section{Acknowledgement}

Authors acknowledge Fundação para a Ciência e a Tecnologia (FCT - MCTES) for its financial support via the projects UIDB/00667/2020 (UNIDEMI) and UIDB/05037/2020.

\section{References}

AICEP Portugal Global (2018, setember). Flashmoldes, Revista Portugal Global, 1-2. Available at: from:http://www.portugalglobal.pt/PT/Biblioteca/Paginas/Detalhe.aspx?documentId=973a35caaead-4ebd-a8e0-71516fb52c0f (accessed 22 april 2019)

Amran, A., Ooi, S.K., Mydin, R.T. and Devi, S.S. (2015), "The Impact of Business Strategies on Online Sustainability Disclosures", Business Strategy and the Environment, Vol. 24 No. 6, pp.551-564. https://doi.org/10.1002/bse.1837

Anunciação, P.F., Brasil, D.X, Marques, J.A., Nunes, Matias, A.P.N., and Garcia, C.P. (2016), "Sustainability Reporting: A Comparative Analysis in Portuguese and Brazilian Major Companies", International Journal of Sustainable Economies Management, Vol. 5 No. 4, pp 10-25.

Ashrafi, M., Adams, M. Walker; T.R. and Magnan, G. (2018), "How corporate social responsibility can be integrated into corporate sustainability: a theoretical review of their relationships", International Journal of Sustainable Development and World Ecology, Vol. 25 No. 8, pp.672-682.

Asif, M., Searcy, C., Zutshi, A., and Ahmad, N. (2011). "An integrated management systems approach to corporate sustainability”, European Business Review, Vol. 23 No, pp.353-367. doi:10.1108/09555341111145744

Bae, S.M., Masud, M.A.K and Kim, J.D. (2018), “A Cross-Country Investigation of Corporate Governance and Corporate Sustainability Disclosure: A Signaling Theory Perspective”, Sustainability, Vol.10, No. 2611, pp. 1-16.

Bansal P, and DesJardine M.R. (2014), "Business sustainability: it is about time”, Strategic Organization, Vol. 12 No 1, pp.70-78.

Bansal, P. (2005), "Evolving Sustainably: a Longitudinal Study of Corporate Sustainable Development", Strategic Management Journal, Vol. 26 No. 3, pp.197-218.

Barako, D.G. and Brown, A.M. (2008), "Corporate social reporting and board representation: evidence from the Kenyan banking sector", Journal of Management and Governance, Vol. 12 No. 4, pp. 09324.

Bolognesi, M., Pilgram, R and van den Heerik, R. (2016), "Reliability in content analysis: The case of semantic feature norms classification”, Behavior Research Methods, Vol. 49 No. 6, pp.1984-2001.

Bosco, B. (2017), “The evolution of CSR communication on the Internet”, Electronic Journal of management, Vol. 1, pp.1-29.

Branco, M. C., Delgado, C. and Marques, C. (2018), "How do sustainability reports from the Nordic and the Mediterranean European countries compare", Review of Managerial Science, Vol.12 No.4, pp.917-936.

Branco, M., Delgado, C., Sá, M. and Sousa, C. (2014), “Comparing CSR communication on corporate web sites in Sweden and Spain”, Public Journal of Management, Vol. 9 No. 2, pp.231-250.

Branco, M.C. and Delgado, C. (2011), "Research on corporate social responsibility and disclosure in Portugal”, Social Responsibility Journal, Vol. 7 No. 2, pp.202-217.

Branco, M.C. and Rodrigues, L.L. (2006). "Communication of Corporate Social Responsibility by Portuguese Banks. A Legitimacy Theory Perspective", Corporate Communications: An International Journal, Vol. 11 No.3, pp.232-248.

Branco, M.C., and Rodrigues, L.L. (2008), "Factors Influencing Social Responsibility Disclosure by Portuguese Companies", Journal of Business Ethics, Vol. 83 No. 4, pp.685-701.

Campbell, D. (2004), "A Longitudinal and Cross Sectional Analysis of Environmental Disclosure in UK Companies: A Research Note”, British Accounting Review, Vol. 36 No. 1, pp.107-117. 
Campbell, D.J. and Beck, A.C. (2004), “Answering allegations: The use of the corporate website for issue-specific reputation management", Business Ethics: A European Review, Vol. 13 No. 2/3, pp.100-116.

Capriotti, P. and Moreno, A. (2007), “Corporate citizenship and public relations: The importance and interactivity of social responsibility issues on corporate websites", Public Relations Review, Vol. 33 No. 184-91, pp.84-91.

Carvalho, F., Santos, G. and Gonçalves, J. (2018), "The disclosure of information on sustainable development on the corporate website of the certified portuguese organizations", International Journal for Quality Research, Vol. 12 No. 1, pp.253-276.

Carvalho, F., Santos, G. and Gonçalves, J. (2019), “Critical analysis of information about integrated management systems and environmental policy on the Portuguese firms' website, towards sustainable development", Corporate Social Responsibility and Environmental Management, Vol. 27 No. 2, pp. 1-20. DOI: $10.1002 /$ csr. 1866

Carvalho, F. (2013). A divulgação de informação sobre sistemas integrados de gestão (SIG), sustentabilidade empresarial (SE) \& responsabilidade social empresarial (RSE), nos websites das empresas portuguesas certificadas: Uma análise exploratória (Dissertação de Mestrado). Instituto Politécnico do Cávado e do Ave, Barcelos, Portugal. Retrieved from http://hdl.handle.net/11110/641

CEFAMOL (2014), Posicionamento competitivo da indústria de moldes, Associação nacional da indústria de moldes.

Chaudhri, V. and Wang, J. (2007), "Communicating corporate social responsibility on the internet", Management Communication Quarterly, Vol. 21 No. 2, pp. 232-247.

Cormier, D. and Magnan, M. (2003), "The impact of the web on information and communication modes: The case of corporate environmental disclosure", International Journal of Technology Management, Vol. 27, No.4, pp.393-416.

Das, M., Rangarajan, K. and Dutta, G. (2020), “Corporate sustainability in small and medium-sized enterprises: a literature analysis and road ahead”, Journal of Indian Business Research, Vol. 12 No. 2, pp. 271-300.

Dias, A., Rodrigues, L., Craig, R. and Neves, M. (2019), "Corporate social responsibility disclosure in small and medium-sized entities and large companies”, Social Responsibility Journal, Vol. 15 No. 2 , pp.137-154. https://doi.org/10.1108/SRJ-05-2017-0090

Dienes, D., Sassen, R. and Fischer, J. (2016), "What are the drivers of sustainability reporting? A systematic review”, Sustainability Accounting, Management and Policy Journal, Vol. 7 No. 2, pp.154-189.

Dincer, C. and Dincer, B. (2010), “An investigation of Turkish small and medium-sized enterprises online CSR communication”, Social Responsibility Journal, Vol. 6 No. 2, pp.197-207.

Dyllick, T. and Hockerts, K. (2002), "Beyond the business case for corporate sustainability”, Business Strategy and the Environment, Vol. 11 No. 2, pp.130-141.

Epstein, M.J. (2008), Making Sustainability Work - Best Practices in Managing and Measuring Corporate Social, Environmental, and Economic Impacts, Greenleaf Publishing, Sheffield, UK. ISBN: 978-1-57675-486-3.

EU Commission. Directive 2014/95/EU of the European Parliament and the Council of 22 October 2014 amending Directive 2013/34/EU as Regards Disclosure of Non-Financial and Diversity Information by Certain Large Undertakings and Groups; EU Commission: Brussels, Belgium, 2014; pp. 1-9.

European Commission (2001), Promoting a European Framework for Corporate Social Responsibility. Green Paper. Available at: https://ec.europa.eu/commission/presscorner/detail/en/DOC_01_9

Ferreira C. (2004), "Environmental accounting: the Portuguese case”, Management of Environmental Quality: an International Journal, Vol 15 No .6, pp.561-573.

Fifka, M. S. (2012), “The development and state of research on social and environmental reporting in global comparison", Journal fur Betriebswirtschaft, Vol. 62 No. 1, pp.45-84. 
Freeman, R.E. and Reed, D.L. (1983), "Stockholders and stakeholders: A new perspective on corporate governance”, California Management Review, Vol. 25 No. 3, pp. 88-106.

Gomes, S.F., Eugénio, T.C.P. and Branco, M.C. (2015), "Sustainability reporting and assurance in Portugal”, Corporate Governance, Vol. 15 No. 3, pp.281-292.

Gray, R., Kouhy, R. and Lavers, S. (1995), “Corporate social and environmental reporting: a review of the literature and a longitudinal study of UK disclosure", Accounting, Auditing and Accountability Journal, Vol. 8 No. 2, pp.47-77.

Gray, R.H., Javad, M., Power D.M. and Sinclair C.D. (2001), "Social and environmental disclosure and corporate characteristics: A research note and extension", Journal of Business Finance and Accounting, Vol. 28 No. 3/4, pp.327-356.

Guthrie, J., Cuganesan, S., and Ward, L. (2008), "Disclosure Media for Social and Environmental Matters within the Australian Food and Beverage Industry", Accounting Forum, Vol. 32 No. 1, pp.1-15.

Hackston, D. and Milne, M.J. (1996), "Some Determinants of Social and Environmental Disclosures in New Zealand Companies”, Accounting, Auditing and Accountability, Vol. 9 No. 1, pp.77-94.

Haddock-Fraser, J. and Fraser, I. (2008), “Assessing corporate environmental reporting motivations: differences between 'close-to-market' and 'business-to-business' companies”, Corporate Social Responsibility and Environment Management, Vol. 15 No. 3, pp. 140-155.

Hahn, R. and Kühnen, M. (2013), "Determinants of sustainability reporting: a review of results, trends, theory, and opportunities in an expanding field of research", Journal of Cleaner Production, Vol. 59, pp.5-21.

Hahn, T., Pinkse, J., Preuss, L., and Figge, F. (2015) "Tensions in corporate sustainability: towards an integrative framework", Journal of Business Ethics, Vol. 127 No. 2, pp. 297-316.

Hamzah, N. and Abdullah, M. (2018), "Stakeholder Power towards Corporate Social and Environmental Responsibility Disclosure: Evidence from Malaysia”, Asian Journal of Accounting and Governance, Vol. 10, pp. 1-10.

Hitchcock, D.E. and Willard, M.L. (2006), The business guide to sustainability: practical strategies and tools for organizations, Earthscan Ltd., London, UK.

Hsieh, H.F. and Shannon, S.E. (2005), "Three approaches to qualitative content analysis", Qualitative Health Research, Vol. 15 No .9, pp.1277-1288.

Isenmann, R., Bey, C. and Welter, M. (2007), “Online reporting for sustainability issues”, Business Strategy and the Environment, Vol. 16 No.7, pp.487-501.

Joseph, C. (2010), "Content analysis of sustainability reporting on Malaysian local authority websites", The Journal of Administrative Science, Vol. 7 No. 1, pp.101-125.

Joseph, C. and Taplin, R. (2011), "The measurement of sustainability disclosure: Abundance versus occurrence”, Accounting Forum, Vol. 35, pp.19-31.

Joseph, C., Lin, V.C.S., Nichol, E.O., and Jussem, P.M. (2014), "Sustainability Disclosure on Malaysian Hotel Websites", in Corporate Social Responsibility Disclosure and Sustainability Reporting 2,International Conference on Governance.

Joshi, P.L., and Gao, S.S. (2009), "Multinational corporations' corporate social and environmental disclosures (CSED) on websites", International Journal of Commerce and Management, Vol. 19 No. 1, pp.27-44

Kaplan, A. and Goldsen, J.M. (1965), “The Reliability of Content Analysis Categories”, in Lasswell, H. D. , Leites, N.C. and Associates (eds.), Language of Politics; Studies in Quantitative Semantics, MIT Press, Cambridge, MA, pp. 83-112.

Kassarjian, H.H. (1977), “Content Analysis in Consumer Research”, Journal of Consumer Research, Vol. 4 No. 1, pp. 8-18. https://doi.org/10.1086/208674

Kiliç M. (2016), "Online corporate social responsibility (CSR) disclosure in the banking industry”, International Journal of Bank Marketing, Vol. 34 No. 4, pp.550-569. 
Kiliç, M., Kuzey, C. and Uyar, A. (2015), "The impact of ownership and board structure on Corporate Social Responsibility (CSR) reporting in the Turkish banking industry", Corporate Governance, Vol. 15, No. 3, pp.357-374.

Krippendorff, K. (2004), "Measuring the Reliability of Qualitative Text Analysis Data", Quality \& Quantity, Vol. 38 No .6, pp.787-800.

Kühn, A., Stiglbauer, M. and Fifka, M.S. (2018), "Contents and Determinants of Corporate Social Responsibility Website Reporting in Sub-Saharan Africa: A Seven-Country Study”, Business and Society, Vol. 57 No. 3, pp.437-480.

Linnenluecke, M.K., Russell, S.V., and Griffiths, A. (2009), "Subcultures and sustainability practices: the impact on understanding corporate sustainability", Business Strategic Environment, Vol. 18 No. 7, pp.432-452.

Lodia, S.K. (2010), "Research methods for analysing World Wide Web sustainability communication", Social and Environmental Accountability Journal, Vol. 30 No. 1, pp. 26-36.

Lozano R. (2011), “Addressing stakeholders and better contributing to sustainability through game theory", Journal of Corporate Citizenship, Vol. 43, pp.45-62.

Maas, K., Schaltegger, S. and Crutzen, N. (2016), "Integrating Corporate Sustainability Assessment, Management Accounting, Control, and Reporting”, Journal of Cleaner Production, Vol. 136, pp.237-248.

Marques P. (2017) "From toys to automobiles: foreign investment, firm heterogeneity and intermediaries in a Portuguese industry”, European Planning Studies, Vol.25, No. 8, pp. 1375-1393.

Marrewijk, M. (2003), "Concepts and Definitions of CSR and Corporate Sustainability: Between Agency and Communion”, Journal of Business Ethics, Vol. 44, No. 2-3, pp.95-105.

Mayring, P. (2000), “Qualitative Content Analysis”, Forum Qualitative Social Research, Vol. 1, No. 2. available at: http://www.qualitative-research.net/index.php/fqs/article/view/1089.

Mitchell, R.K., Agle, B.R. and Wood, D.J. (1997), “Toward a theory of stakeholder identification and salience: Defining the principle of who and what really counts", Academy of Management Review, Vol. 22, No.4, pp.853-886.

Monteiro, M.S.S., and Aibar-Guzmán, B. (2010), "Determinants of Environmental Disclosure in the Annual Reports of Large Companies Operating in Portugal”, Corporate Social Responsibility and Environmental Management, Vol. 17, No. 4, pp.185-204.

Montiel I. 2008. "Corporate social responsibility and corporate sustainability separate pasts, common futures”, Organizational Environment, Vol 21, No 3, pp.245-269.

Morhardt, J.E. (2010), “Corporate social responsibility and sustainability reporting on the Internet”, Business Strategy and the Environment, Vol. 19, No. 7, pp.436-452.

Mura, M., Longo, M.., Domingues, A.R., and Zani, S. (2019), “An Exploration of Content and Drivers of Online Sustainability Disclosure: A Study of Italian Organisations”, Sustainability, Vol. 11, No.12, p.3422.

Nili, A., Tate, M., and Barros, A. (2017), “A critical analysis of inter-coder reliability methods in information systems research". In Riemer, K, Indulska, M, and Tuunainen, V (Eds.) Proceedings of the 28th Australasian Conference on Information Systems. University of Tasmania, Australia, pp. 111.

O’Dwyer, B. (2003), “The ponderous evolution of corporate environmental reporting in Ireland: Recent evidence from publicly listed companies", Corporate Social Responsibility and Environmental Management, Vol. 10, No. 20, pp.91-100.

Okongwu, U., Morimoto, R. and Lauras, M. (2013), "The maturity of supply chain sustainability disclosure from a continuous improvement perspective", International Journal of Productivity and Performance Management, Vol. 62, No. 8, pp.827-855.

Omoloso, O., Wise, W.R., Mortimer, K., and Jraisat, L. (2020). “Corporate Sustainability Disclosure: A Leather Industry Perspective, Emerging Science Journal, Vol. 4, No. 1, pp.44- 51 
PBA, Portuguese Business Association, (2019) (available at: , http://www.aeportugal.pt/Aplicacoes/SectoresEmpresariais/Top100.asp?IDSector=18).

Qian, W., Tilt, C., Dissanayake, D. and Kuruppu, S. (2020), "Motivations and impacts of sustainability reporting in the Indo-Pacific region: Normative and instrumental stakeholder approaches", Business Strategy and the Environment, pp.1-15.

Raghupathi, V. and Raghupathi, W. (2019), "Corporate sustainability reporting and disclosure on the web: an exploratory study”, Information Resources Management Journal, Vol. 32, No. 1, pp.1-27.

Rahim, N. and Omar, N. (2017), "Online Communication and Sustainability Reporting: The Managerial Issues”, Malaysian Journal of Communication, Vol. 33, No. 3, pp.231-249.

Ramos, T.A.B., Cecília, T, Douglas, C.H. and Caeiro, S. (2013), "Corporate sustainability reporting and the relations with evaluation and management frameworks: the Portuguese case", Journal of Cleaner Production, Vol. 52, pp.317-328.

Reilly A. H. and Larya, N. (2018), "External communication about sustainability: Corporate Social Responsibility Reports and Social Media Activity", Environmental Communication, Vol. 12, No. 5, pp.621-637.

Ribeiro, V.P.L., Monteiro, S. and Moura, A.M. (2016), "Determinants of sustainability e-reporting in Portuguese municipalities: An institutional and legitimacy theoretical framework", Corporate Responsibility and Stakeholding (Developments in Corporate Governance and Responsibility), Vol. 10, pp.131-163.

Rikhardsson, P., Anderson, A. and Bang, H. (2002), "Sustainability reporting on the internet: A study of the global fortune 500”, Greener Management International, Vol. 40, pp.57-75.

Robalo, R. and Patrocínio, W. (2018), "CRS disclosure on the websites of portuguese foundations " in GECAMB2018 - Conference on Environmental Management and Accounting proceedings proceedings, Portugal, 2018, 8-9 november, Setúbal, pp. 529-547.

Scott, W.R. (1995), Institutions and Organizations, Thousand Oaks, CA, Sage.

Servera-Francés, D. and Arteaga-Moreno, F. (2015), "The impact of corporate social responsibility on the customer commitment and trust in the retail sector", Ramon Llull Journal of Applied Ethics, Vol. 6, pp.161-178.

Seuring, S. and Gold, S. (2013), "Sustainability management beyond corporate boundaries: from stakeholders to performance", Journal of Cleaner Production, Vol. 56, pp.1-6.

Shoaf, V., Jermakowicz, E. K.,Epstein, B. J. (2018) “Toward Sustainability and Integrated Reporting”. Review of Business, Vol. 38, No. 1, pp. 1-15.

Siano, A., Conte, F., Amabile, S., Vollero, A. and Piciocchi, P. (2016), “Communicating Sustainability: An Operational Model for Evaluating Corporate Websites”, Sustainability, Vol. 8, No. 950, pp.1-16.

Siew, R. Y. J. (2015), “A review of corporate sustainability reporting tools (SRTs)”, Journal of Environmental Management, Vol. 164, pp.180-195.

Sobhani, F. A., Amran, A. and Zainuddin, Y. (2012), "Sustainability disclosure in annual reports and websites: a study of the banking industry in Bangladesh", Journal of Cleaner Production, Vol. 23, pp. $75-85$.

Solomon, J. (2010). Corporate Governance and Accountability, 3rd Edition, John Wiley and Sons, Chichester.

Srai, J.S., Alinaghian, L.S. and Kirkwood, D.A. (2013), "Understanding sustainable supply network capabilities of multinationals: A capability maturity model approach", Proceedings of Institute of Mechanical Engineers Part B: Journal of Engineering Manufacture, Vol. 227, No. 4, pp.595-615.

Steurer, R., Langer, M. E., Konrad, A. and Martinuzzi, A. (2005), “Corporations, Stakeholders and Sustainable Development I: A Theoretical Exploration of Business-Society Relations", Journal of Business Ethics, Vol. 61, No. 3, pp.263-281.

Suchman, M.C. (1995), "Managing legitimacy: strategy and institutional approaches”, Academy of Management Review, Vol. 20, No. 3, pp.571 - 610. 
Tagesson, T., Blank, V., Broberg, P. and Collin, S. (2009), "What explains the extent and content of social and environmental disclosures on corporate websites: a study of social and environmental reporting in Swedish listed corporations", Corporate Social Responsibility and Environmental Management, Vol. 16, No. 6, pp.352-364.

Tang, L. and Li, H. (2009), "Corporate social responsibility communication of Chinese and global corporations in China”, Public Relations Review, Vol. 35, No. 3, pp.199-212.

Tang, L., Gallagher, C.C. and Bie, B. (2015), "Corporate social responsibility communication through corporate websites: a comparison of leading corporations in the United States and China", International Journal of Business Communication, Vol. 52, No. 2, pp.205-227.

Thun, J.H. and Müller, A. (2010), “An empirical analysis of green supply chain management in the german automotive industry", Business Strategy and the Environment, Vol. 19, No. 2, pp.119-132.

Tremblay-Boire, J. and Prakash, A. (2014), “Accountability.org: online disclosures by U.S. Nonprofits”, International Journal of Voluntary and Nonprofit Organizations, Vol. 26, No .2, pp.693-719.

Truant, E., Corazza, L. and Scagnelli, S. (2017). "Sustainability and risk disclosure: an exploratory study on sustainability reports”, Sustainability, Vol. 9, pp.636-647.

Tsalis, T.A, Malamateniou, K. E., Koulouriotis, D., Nikolaou, I. E. (2020) "New challenges for corporate sustainability reporting: United Nations' 2030 Agenda for sustainable development and the sustainable development goals", Corporate Social Responsibility and Environmental management.

Van der Laan, S.J., Adikhari, A. and Tondkar, R.H. (2005), "Exploring differences in social disclosures internationally: a stakeholder perspective", Journal of Accounting and Public Policy, Vol. 24, No. 2, pp.123-151.

Virakul, B. and Russ-Eft, D. F. (2020), “A model for business responses to global challenges and sustainable development”, Social responsibility Journal, Vol. 16, No. 2, pp.199-224.

Weber, R. P. (1990). Basic Content Analysis. 2nd Edition. Sage Publications. London. On-line ISBN: 9781412983488

Williams, S.M. and Pei, C.H.W. (1999), “Corporate Social Disclosures by Listed Companies on their Web Sites: An International Comparison”, International Journal of Accounting, Vol. 34, No. 3, pp. 389-419. 
Appendix A. List of companies under sample

\begin{tabular}{|c|c|c|c|}
\hline Code & Company Name & $\underline{\text { Dimension/size }}$ & $\begin{array}{c}\frac{\text { Website }}{\text { (Retrived from February and }} \\
\text { March 2019) }\end{array}$ \\
\hline COM1 & $\begin{array}{l}\text { 3DTECH - PRODUÇÃO, OPTIMIZAÇÃO E REENGENHARIA } \\
\text { LDA }\end{array}$ & Small & https://www.3dtech.pt \\
\hline COM2 & A \& M - MOLDES PARA PLÁSTICOS, LDA. & $\underline{\text { Small }}$ & https://www.ammoldes.com \\
\hline COM3 & A. SILVA, GODINHO \& CIA., LDA. & Medium & https://www.asg.pt \\
\hline COM4 & AES-ADVANCED ENGINEERING SOLUTIONS, MOLDES, LDA. & Micro & https://www.aesmolds.com \\
\hline COM5 & $\begin{array}{l}\text { AFR MOLDES - FABRICAÇÃO DE MOLDES PARA PLÁSTICOS, } \\
\text { LDA. }\end{array}$ & $\underline{\text { Small }}$ & https://www.eng-tooling.pt \\
\hline COM6 & $\begin{array}{l}\text { ANIBAL H. ABRANTES - INDÚSTRIAS DE MOLDES E } \\
\text { PLÁSTICOS, S.A }\end{array}$ & Medium & http://www.aha.pt \\
\hline COM7 & ANTÓNIO CUNHA LEITE, LDA. & Medium & https://www.aclmoldes.com \\
\hline COM8 & AURIMOLDES - INDUSTRIA DE MOLDES, LDA. & $\underline{\text { Small }}$ & https://www.aurimoldes.com \\
\hline COM9 & AZEMOLDES - MOLDES DE AZEMEIS, LDA. & Medium & http://www.azemoldes.pt \\
\hline COM10 & DEXPROM - PRODUÇÃO DE MOLDES, LDA & Medium & https://www.dexprom.com \\
\hline COM11 & DRT RAPID - PROTÓTIPOS E MOLDES, LDA & Medium & https://drtmoldes.com/pt \\
\hline COM12 & E\&T - ENGINEERING AND TOOLING, LDA. & $\underline{\text { Small }}$ & https://www.eng-tooling.pt \\
\hline COM13 & EROFIO - ENGENHARIA E FABRICAÇÃO DE MOLDES, S.A. & Medium & https://www.erofio.pt \\
\hline COM14 & $\begin{array}{l}\text { FAMIKRON - FÁBRICA DE CORTANTES, MOLDES E PEÇAS } \\
\text { DE PRECISÃO, S.A. }\end{array}$ & $\underline{\text { Small }}$ & https://www.famikron.pt \\
\hline COM15 & $\begin{array}{l}\text { FAMOLDE - FABRICAÇÃO E COMERCIALIZAÇÃO DE } \\
\text { MOLDES, S.A. }\end{array}$ & Medium & $\underline{\mathrm{http}: / / \mathrm{www} . \mathrm{gln} . \mathrm{pt} / \mathrm{pt} / \mathrm{GLN} /}$ \\
\hline COM16 & FAMPLAC - MOLDES, LDA. & Small & https://www.famplac.pt \\
\hline COM17 & FJN-FABRICO DE MOLDES DE PRECISÃO, LDA. & $\underline{\text { Small }}$ & https://www.fjn.pt \\
\hline COM18 & FMP-FABRICA DE MOLDES PARA PLASTICOS, LDA & $\underline{\text { Micro }}$ & http://www.fmpmoldes.pt \\
\hline COM19 & FOZMOLDES, LDA & $\underline{\text { Small }}$ & https://www.fozmoldes.com \\
\hline COM20 & $\begin{array}{l}\text { GECO-GABINETE TÉCNICO E CONTROLO DE MOLDES EM } \\
\text { FABRICAÇÃO, LDA. }\end{array}$ & Medium & $\underline{\text { https://geco-moldes.pt }}$ \\
\hline COM21 & GEOCAM - MAQUINAÇÃO E MOLDES, LDA & $\underline{\text { Small }}$ & $\underline{\text { https://www.geocam.pt }}$ \\
\hline COM22 & $\begin{array}{l}\text { IBERONORMA - ESTRUTURAS E ACESSÓRIOS PARA } \\
\text { MOLDES, LDA. }\end{array}$ & $\underline{\text { Small }}$ & https://www.iberonorma.pt \\
\hline $\operatorname{COM} 23$ & IDEAL MOLDE - INDÚSTRIA DE MOLDES E PLÁSTICOS, LDA & Medium & $\underline{\mathrm{http}: / / \mathrm{www} . \text { idealmolde.com }}$ \\
\hline COM24 & IMOPLASTIC - INDUSTRIA DE MOLDES E PLÁSTICOS, LDA. & Medium & $\underline{\text { https://www.imoplasticgroup.pt }}$ \\
\hline $\operatorname{COM} 25$ & IMTEC - INDÚSTRIA DE MOLDES TÉCNICOS, LDA. & $\underline{\text { Small }}$ & https://www.imtec-moldes.com \\
\hline COM26 & INTERMOLDE - MOLDES VIDREIROS INTERNACIONAIS, LDA. & Medium & $\underline{\text { http://www.intermolde.pt }}$ \\
\hline COM27 & IRMÃOS MELO, LDA & $\underline{\text { Small }}$ & https://www.irmel.pt \\
\hline COM28 & ITJ - INTERNACIONAL MOLDES, LDA. & Medium & $\underline{\text { https://www.tj-moldes.pt }}$ \\
\hline COM29 & ITM - INDUSTRIA TÉCNICA DE MOLDES, LDA. & $\underline{\text { Small }}$ & https://www.itm.com.pt \\
\hline COM30 & J.R. RIBEIRO, MOLDES, LDA. & $\underline{\text { Small }}$ & $\underline{\text { https://www.jrmoldes.com/pt }}$ \\
\hline COM31 & JAR - MOLDES, LDA. & $\underline{\text { Small }}$ & $\underline{\mathrm{http}: / / \mathrm{www} . j \operatorname{armoldes} . c o m / \mathrm{pt} /}$ \\
\hline COM32 & JDD - MOLDES PARA A INDUSTRIA DE PLÁSTICOS, LDA. & Medium & http://www.jddmoldes.pt \\
\hline COM33 & JOFERLIZ - MOLDES E ACESSÓRIOS, LDA. & $\underline{\text { Small }}$ & http://www.joferlis.com \\
\hline COM34 & $\begin{array}{l}\text { LISMOLDE - INDUSTRIA DE MOLDES PARA MATÉRIAS } \\
\text { PLÁSTICAS LDA }\end{array}$ & Medium & $\underline{\text { https://www.lismoldegroup.pt }}$ \\
\hline COM35 & MACRO-MOLDES PARA PLASTICOS LDA & $\underline{\text { Small }}$ & https://www.macrogroup.eu \\
\hline COM36 & MB LUSITANA DE MATRIZES, S A & $\underline{\text { Small }}$ & http://www.mbtooling.com/mblusitana/ \\
\hline COM37 & MD FASTOOLING, LDA. & $\underline{\text { Small }}$ & https://www.md-fastooling.com \\
\hline COM38 & MEGATECHIND - INDÚSTRIAS MARINHA GRANDE, LDA & $\underline{\text { Small }}$ & $\underline{\text { https://www.megatech-industries.com/pt }}$ \\
\hline COM39 & MELCYLIX - ENGENHARIA DE PROJECTOS DE METAIS, LDA & $\overline{\text { Small }}$ & https://www.melcylix.pt \\
\hline COM40 & $\begin{array}{l}\text { METAVIL - EMPRESA TRANSFORMADORA METALO } \\
\text { VIDREIRA, LDA. }\end{array}$ & Small & https://www.metavil.pt \\
\hline COM41 & $\begin{array}{l}\text { MOLCER - MOLDES E EQUIPAMENTOS CERAMICOS } \\
\text { UNIPESSOAL, LDA. }\end{array}$ & $\underline{\text { Small }}$ & https://molcer.pt \\
\hline COM42 & MOLD WORLD - TECNOLOGIA DE MOLDES, S.A & Medium & $\underline{\text { https://www.moldworld.pt }}$ \\
\hline
\end{tabular}




\begin{tabular}{|c|c|}
\hline Small & https://www.moldata.pt \\
\hline Medium & http://www.moldegama.com \\
\hline Medium & $\underline{\text { https://www.moldene.pt }}$ \\
\hline$\underline{\text { Small }}$ & https://www.moldescatarino.pt \\
\hline$\underline{\text { Small }}$ & https://www.moldesd4.pt \\
\hline$\underline{\text { Small }}$ & $\underline{\text { https://www.mop-molds.com }}$ \\
\hline Medium & https://www.moldesrp.pt \\
\hline Medium & https://www.moldetipo.pt \\
\hline Medium & http://www.moldit.pt \\
\hline Medium & https://www.grupomoldoeste.com \\
\hline Medium & http://www.moldoplastico.com \\
\hline$\underline{\text { Small }}$ & $\underline{\text { https://www.mptool.pt }}$ \\
\hline$\underline{\text { Small }}$ & https://normolde.pt \\
\hline$\underline{\text { Small }}$ & http://www.olesa.pt \\
\hline & \\
\hline
\end{tabular}

COM57 P.M.M. - PROJECTOS, MOLDES, MANUFACTURA, LDA

COM58 PLÁCIDO ROQUE - INDÚSTRIA DE MOLDES E MÁQUINAS, LDA.

COM59 PLANFURO MOLDES EM AÇO - RECTIFICAÇÃO, FURAÇÃO E FREZAGEM, S.A

COM60 PLANIMOLDE - FABRICO E COMÉRCIO DE MOLDES, S.A.

COM61 PLANITEC - MOLDES TÉCNICOS, LDA

COM62 PORTUMOLDE-MOLDES PORTUGUESES, LDA

COM63 PRIFER - INDUSTRIA DE MOLDES, LDA

COM64 PROCADIMOLDES - FABRICAÇÃO E COMERCIO DE MOLDES, LDA.

COM65 PVS 2 - FAST TOOLING, S.A

COM66 RECTIMOLD - RECTIFICAÇÃO DE MOLDES, S.A

COM67 RIBERMOLD, LDA

COM68 SÁMOLDES, INDÚSTRIA DE MOLDES, UNIPESSOAL LDA

COM69 SEDLOM - SOCIEDADE DE MOLDES DE PRECISÃO, LDA.

COM70 SETSA - SOCIEDADE DE ENGENHARIA E TRANSFORMAÇÃO, S.A

COM71 SILVASTEC-MOLDES E PLÁSTICOS S.A.

COM72 SOCÉM - E. D. - FABRICAÇÃO, ENG.DESENVOLVIMENTO DE MOLDES, S.A.

COM73 SOCEM - M. S. - FABRICAÇÃO DE MOLDES DE INJECÇÃO LDA

COM74 SOCIEDADE METALURGICA MARINHENSE, LDA.

COM75 STEELPLUS - MOLDES TECNICOS, LDA

COM76 TECNIFREZA - INDÚSTRIA DE MOLDES, S.A.

COM77 TECNIJUSTA - AJUSTAMENTOS E MOLDES PARA PLÁSTICOS, UNIPESSOAL, LDA

COM78 TECNIMOPLAS - INDUSTRIA TECNICA DE MOLDES LDA

COM79 TETRAMOLD - INDUSTRIA DE MOLDES, LDA

COM80 TJ AÇOS, LDA

COM81 TJ MOLDES, S.A.

COM82 V.S.V-MODELAÇÃO, MAQUINAÇÃO E MOLDES, LDA.

COM83 VIDRIMOLDE-INDUSTRIA INTERNACIONAL DE MOLDES, LDA $\underline{\text { Small }}$

$\underline{\text { Small }}$

$\underline{\text { Small }}$

$\underline{\text { Small }}$

$\underline{\text { Small }}$

Medium

$\underline{\text { Small }}$

$\underline{\text { Small }}$

$\underline{\text { Small }}$

Medium

Micro

$\underline{\text { Small }}$

Medium

Small

Medium

Small

Medium

$\underline{\text { Small }}$

Medium

$\underline{\text { Small }}$

Medium

$\underline{\text { Small }}$

Medium

Medium

$\underline{\text { Small }}$

$\underline{\text { Small }}$ https://www.placidoroque.pt

https://www.planfuroglobal.pt

http://www.planimolde.pt

https://www.planitec.pt

https://www.portumolde.pt

http://www1.prifer.pt

http://procadimoldes.pt

http://www.pvsmoldes.eu

https://www.rectimold.pt

https://www.ribermold.pt

https://www.samoldes.com

https://www.sedlom.pt

https://www.iberomoldes.pt/setsa

https://www.silvastec.pt

https://socem.pt

https://www.socem.pt

https://www.somema.pt

https://www.steelplus.pt

http://www.tecnifreza.pt

https://www.tecnijusta.pt

https://www.tecnimoplas.pt

https://www.tetramold.pt

https://www.tj-moldes.pt

https://www.tj-moldes.pt

http://vsv.pt/

http://www.vidrimolde.pt 


\section{Appendix B. Codebook}

This codebook includes three main parts: the categories used to capture the sustainability-related information according to the categories proposed in table 2 , the respective description and an example, and the inclusion/exclusion criteria. The examples were generated while developing the codebook and coding the first transcript. It should be note that the examples were translated from Portuguese to English.

Two native speakers of Portugal coded all the websites. A pre-test was performed to code book, diffuse and resolve disagreements in coding categories and clarifying the meaning of each category.

\begin{tabular}{|c|c|c|c|}
\hline Code & Description & Example & Inclusion/Exclusion criteria \\
\hline $\begin{array}{l}\text { C1. Structure of the } \\
\text { corporate website } \\
\text { and format of } \\
\text { information }\end{array}$ & \multicolumn{3}{|c|}{$\begin{array}{l}\text { This category aims to aims to characterize the structure of the company's website in terms of the dissemination of information. Implies identification of the information disclosed on } \\
\text { corporate sustainability and the pages where it is presented, as well as the format in which that information is presented. } \\
\text { (Difference between webpage and website at: https://www.websiteplanet.com/blog/website-vs-webpage-difference/) }\end{array}$} \\
\hline $\begin{array}{l}\text { 1. The website } \\
\text { displays the theme } \\
\text { of corporate } \\
\text { sustainability }\end{array}$ & $\begin{array}{l}\text { This subcategory includes all statements made available by companies on their website that } \\
\text { refer to corporate sustainability and any information related to the areas related with } \\
\text { products and services, economic action, customers, suppliers, environment, human } \\
\text { resources and community involvement. The pages where these statements are presented are } \\
\text { identified. }\end{array}$ & $\begin{array}{l}\text { "... has its own integrated management } \\
\text { project that aims for sustainability and } \\
\text { stakeholder involvement. We feel } \\
\text { responsible, not only for our companies, } \\
\text { but also for every single person working } \\
\text { with us, our society, and the environment". }\end{array}$ & $\begin{array}{l}\text { Inclusion: All statements presented, on all } \\
\text { relevant webpages of the website, which } \\
\text { include all information on and regarding } \\
\text { corporate sustainability. Information on } \\
\text { "sustainability", "sustainable development" or } \\
\text { "corporate social responsibility" is included, if } \\
\text { related to the company under study. } \\
\text { Exclusion: Information on non-relevant } \\
\text { webpages, for example, related to locations and } \\
\text { contacts are excluded. Information not related } \\
\text { with the economic, social, and environmental } \\
\text { dimensions }\end{array}$ \\
\hline $\begin{array}{l}\text { 2. The website } \\
\text { displays information } \\
\text { through text and/or } \\
\text { images }\end{array}$ & $\begin{array}{l}\text { Information disclosed on corporate sustainability can be conveyed through text, images } \\
\text { (symbols, photos, video) or text and images }\end{array}$ & $\begin{array}{l}\text { Text: "we make it } \\
\text { real...environmentally friendly" } \\
\text { Text and image: }\end{array}$ & $\begin{array}{l}\text { Inclusion: Information on and related to } \\
\text { corporate sustainability in text form. Symbols, } \\
\text { photos, or videos are included only if they do } \\
\text { not give rise to any interpretation concerns or } \\
\text { are subtitled or inserted in pages or sections } \\
\text { related to corporate sustainability } \\
\text { Exclusion: Symbols, photos, or videos in which } \\
\text { there are doubts regarding its relationship with } \\
\text { corporate sustainability }\end{array}$ \\
\hline $\begin{array}{l}\text { C2 - Manuals, } \\
\text { codes and other } \\
\text { corporate documents }\end{array}$ & \multicolumn{3}{|c|}{$\begin{array}{l}\text { Documents that formalize the company's systems and behavioral guidance that can contribute to corporate sustainability. This category aggregates the different manuals, codes and other } \\
\text { corporate documents identified in the subcategories } 3,4, \ldots, 12 \text { found on the company's website }\end{array}$} \\
\hline
\end{tabular}




\begin{tabular}{|c|c|c|c|}
\hline 3. Quality manual & $\begin{array}{l}\text { It is a "document that specifies an organization's quality management system" (NP EN ISO } \\
9000: 2005, \text { p. } 24 \text { ) }\end{array}$ & \multirow{10}{*}{ 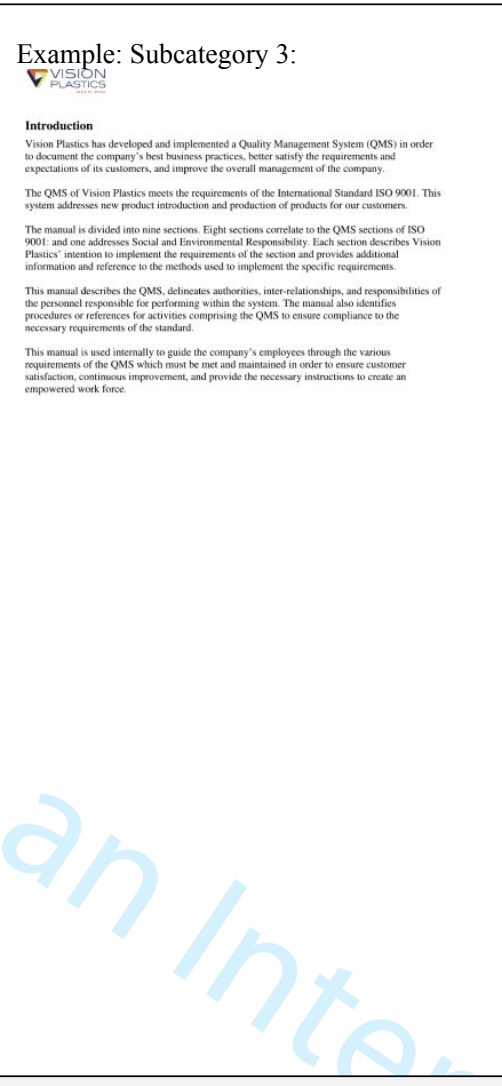 } & \multirow{10}{*}{$\begin{array}{l}\text { Inclusion: Any document presented on the } \\
\text { website (anyplace) or document available for } \\
\text { download and that expressly mentions the } \\
\text { document designation. } \\
\text { Exclusion: Documents other than those } \\
\text { associated with each of the subcategories }\end{array}$} \\
\hline $\begin{array}{l}\text { 4. Environmental } \\
\text { manual }\end{array}$ & $\begin{array}{l}\text { It is the reference document for the environmental management system. "It describes the } \\
\text { organization, the processes and the system, in terms of coordination and control of } \\
\text { activities, establishes the policy and the organization to develop it" (Pinto, 2005a, p. 36). }\end{array}$ & & \\
\hline $\begin{array}{l}\text { 5. Occupational } \\
\text { health and safety } \\
\text { manual }\end{array}$ & $\begin{array}{l}\text { It is the "document that describes the occupational health and safety system and how the } \\
\text { organization complies with applicable requirements" (Santos et al., 2008, p. 111) }\end{array}$ & & \\
\hline $\begin{array}{l}\text { 6. Human resources } \\
\text { manual }\end{array}$ & $\begin{array}{l}\text { It is the document that specifies an organization's human resources management system } \\
\text { (adapted from NP 4427: } 2004 \text { and NP EN ISO 9000: 2005) }\end{array}$ & & \\
\hline $\begin{array}{l}\text { 7. Sustainability } \\
\text { manual }\end{array}$ & $\begin{array}{l}\text { It is the document that specifies an organization's sustainability management system } \\
\text { (adapted from GRI, } 2006 \text { and NP EN ISO 9000: 2005) }\end{array}$ & & \\
\hline $\begin{array}{l}\text { 8. Social } \\
\text { responsibility } \\
\text { manual }\end{array}$ & $\begin{array}{l}\text { It is the document that specifies an organization's social responsibility management system } \\
\text { (adapted from NP 4469-1: } 2008 \text { and NP EN ISO 9000: 2005) }\end{array}$ & & \\
\hline $\begin{array}{l}\text { 9. Code of good } \\
\text { practices }\end{array}$ & $\begin{array}{l}\text { It is the "document that recommends practices or procedures for the design, manufacture, } \\
\text { installation, maintenance or use of equipment, structures or products" (NP EN 45020: } \\
2009 \text {, p. 15) }\end{array}$ & & \\
\hline $\begin{array}{l}\text { 10. List of } \\
\text { environmental } \\
\text { impacts and safety } \\
\text { risks }\end{array}$ & $\begin{array}{l}\text { List of Environmental Aspects / Impacts \& Hazards / Professional Risks the company must } \\
\text { keep documented (list) and updated the information related to its environmental aspects / } \\
\text { impacts (NP EN ISO 14001: 2012) and professional hazards / risks (OHSAS 18001: 2007; } \\
\text { NP 4397: 2008). The company must communicate this information internally and decide } \\
\text { on its external communication (NP EN ISO 14001: 2012; OHSAS 18001: 2007; NP 4397: } \\
\text { 2008). }\end{array}$ & & \\
\hline $\begin{array}{l}\text { 11. Code of ethics } \\
\text { and corporate } \\
\text { conduct }\end{array}$ & $\begin{array}{l}\text { It is the formal document that establishes general ethical objectives that the organization } \\
\text { intends to achieve and pursue, internally and externally, serving the various stakeholders. It } \\
\text { consists of the organization's system of values and commitments, assumed by people as } \\
\text { members of the organization (NP } 4460-1: 2007 \text { ) }\end{array}$ & & \\
\hline $\begin{array}{l}\text { 12. Corruption risk } \\
\text { management plan }\end{array}$ & $\begin{array}{l}\text { It is the document issued by the top management bodies of the management entities of } \\
\text { public money, values or assets, whatever their nature, administrative or business, of public } \\
\text { or private law, must publicize on the website of the respective entity on the Internet the } \\
\text { document entitled plan for the prevention of risks of corruption and related infractions } \\
\text { (Recommendation No. 1/2009; Recommendation No. } 1 / 2010 \text { ) }\end{array}$ & & \\
\hline \multicolumn{4}{|c|}{$\begin{array}{l}\text { C3 - Reports and corporate statements } \\
\text { Documents that formalize the company's commitment to sustainability and / or its dimensions and / or report its objectives / policies / actions/performance. This category aggregates the different reports and } \\
\text { corporate statements, identified in the subcategories } 13,14, \ldots, 21, \text { found on the company's website }\end{array}$} \\
\hline $\begin{array}{l}\text { 13. Sustainability } \\
\text { report }\end{array}$ & $\begin{array}{l}\text { Sustainability Report is a document that aims in "practice, measurement, dissemination and } \\
\text { accountability for organizational performance, with the objective of sustainable } \\
\text { development. A sustainability report is a balanced and reasonable representation of the } \\
\text { reporting organization's sustainability performance, including positive and negative } \\
\text { contributions" (GRI, 2006, p. 44). }\end{array}$ & \multirow[t]{2}{*}{$\begin{array}{l}\text { Example - subcategory 17: } \\
\text { "See 2018 management report } \\
\text { (https://www.moldetipo.pt/images/Relatori } \\
\text { o_gestao_contas_Moldetipo_2018.pdf)" }\end{array}$} & \multirow{2}{*}{$\begin{array}{l}\text { Inclusion: Any document presented in the } \\
\text { company website (anyplace) or document } \\
\text { available for download and that expressly } \\
\text { mentions the report designation. } \\
\text { Exclusion: Documents other than those } \\
\text { associated with each of the subcategories }\end{array}$} \\
\hline $\begin{array}{l}\text { 14. Social } \\
\text { responsibility report }\end{array}$ & $\begin{array}{l}\text { "Reports information on social responsibility, policies and programs, integration of social } \\
\text { and environmental issues in the company's activities and interaction with stakeholders. It is } \\
\text { a voluntary tool, which means that companies develop projects in the social and }\end{array}$ & & \\
\hline
\end{tabular}




\begin{tabular}{|c|c|c|c|}
\hline 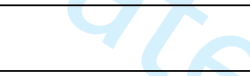 & $\begin{array}{l}\text { environmental fields beyond what is required by law, thus contributing to sustainable } \\
\text { development" (Chen \& Bouvain, 2008) }\end{array}$ & & \\
\hline $\begin{array}{l}\text { 15. Environmental } \\
\text { report }\end{array}$ & $\begin{array}{l}\text { "Its main objective is to communicate environmental issues and business performance to its } \\
\text { stakeholders. It manifests itself as a tool capable of disseminating environmental } \\
\text { objectives, environmental management systems, environmental policies, and corporate } \\
\text { responsibility in the area of the environment. These reports are published for interested } \\
\text { parties in general, to draw conclusions through the information disclosed on the } \\
\text { relationship between economic and environmental performance and compliance with } \\
\text { legislation" (Wagner, 2005) }\end{array}$ & & \\
\hline $\begin{array}{l}\text { 16. Occupational } \\
\text { health and safety } \\
\text { report }\end{array}$ & $\begin{array}{l}\text { "Document reporting the issues of occupational health and safety management in the } \\
\text { organization, which can be issued under compliance with applicable legal requirements" } \\
\text { Carvalho (2013) }\end{array}$ & & \\
\hline $\begin{array}{l}\text { 17. Annual report or } \\
\text { corporate report }\end{array}$ & $\begin{array}{l}\text { Annual report is a document of "rendering of accounts that, like the financial statements, } \\
\text { common or specific, of the private and public entities, aims to provide information of an } \\
\text { economic, financial and social nature about those entities to a wide range of users of that } \\
\text { information" (Pascoal \& Ribeiro, 2001, p. 2). The Management Report "has as main } \\
\text { objective to provide a global view of the company's activity, explaining the reasons for the } \\
\text { past, present and future evolution of its business through, for example, the analysis of } \\
\text { financial, production or performance data" (Pardal, 2007, p. 10). }\end{array}$ & & \\
\hline 18. Accounts report & $\begin{array}{l}\text { Document that "constitutes the institutional basis for the provision of financial information } \\
\text { abroad. This accountability can be divided into two important sets of information: the } \\
\text { management report and the financial statements" (Pardal, 2007, p. 10) }\end{array}$ & & \\
\hline 19. Financial report & $\begin{array}{l}\text { Document that seeks to "provide in a standardized way, information about the financial } \\
\text { position, performance and changes in the financial position of a company that is useful to a } \\
\text { wide range of users in making economic decisions" (Pardal, 2007, p. 10). }\end{array}$ & & \\
\hline $\begin{array}{l}\text { 20. Corporate } \\
\text { governance report }\end{array}$ & $\begin{array}{l}\text { Document that arises from the "duty of presentation, by listed companies, of a declaration } \\
\text { on corporate governance, included in the annual report, explaining the respective } \\
\text { governance practices" (Silva et al. 2006, p. 49). }\end{array}$ & & \\
\hline $\begin{array}{l}\text { 21. Environmental } \\
\text { statement }\end{array}$ & $\begin{array}{l}\text { It is a legal requirement of Environmental Assessment processes, under the terms of } \\
\text { national and community legislation. It is the document to support information about the } \\
\text { decision, which must be disclosed to the public and to the entities consulted in each } \\
\text { process, for the sake of procedural transparency (APA, 2020). }\end{array}$ & & \\
\hline $\begin{array}{l}\text { C4 - Certificates } \\
\text { and corporate } \\
\text { registrations }\end{array}$ & \multicolumn{3}{|c|}{$\begin{array}{l}\text { Certificates of conformity and corporate registrations: i) Certificates of conformity is a "document issued according to the rules of a certification system, which gives confidence that a } \\
\text { product, process or service, properly identified, complies with a standard or other specific normative document" (NP EN } 45020: 2001, \text { p. } 35 \text { ); ii) Registration is the "procedure by which an } \\
\text { organism indicates the relevant characteristics of a product, process or service, or the specific qualities of an organism or an individual, in an appropriate and publicly accessible list" (NP } \\
\text { EN } 45020: 2001, p .30 \text { ). } \\
\text { This category aggregates the different certificates and corporate registrations, identified in the subcategories } 22,23, \ldots, 27 \text {, found on the company's website }\end{array}$} \\
\hline $\begin{array}{l}\text { 22. Certificate of } \\
\text { conformity QMS } \\
\text { (ISO 9001) }\end{array}$ & Certificate that guarantees compliance with the quality management system (ISO 9001) & \multirow{2}{*}{$\begin{array}{l}\text { Example - subcategory 22: } \\
\text { "see our licenses: Azemoldes IQNet ISO } \\
\text { 9001:2015" }\end{array}$} & \multirow{2}{*}{$\begin{array}{l}\text { Inclusion: Any document presented in the } \\
\text { website (anyplace) or document available for } \\
\text { download and that expressly mentions the } \\
\text { certificate designation. } \\
\text { Exclusion: Documents other than those } \\
\text { associated with each of the subcategories }\end{array}$} \\
\hline $\begin{array}{l}\text { 23. Certificate of } \\
\text { conformity EMS } \\
\text { (ISO 14001/ EMAS } \\
\text { III) }\end{array}$ & $\begin{array}{l}\text { Certificate that guarantees compliance with the environmental management system (ISO } \\
\text { 14001/EMAS) }\end{array}$ & & \\
\hline
\end{tabular}




\begin{tabular}{|c|c|c|c|}
\hline $\begin{array}{l}\text { 24. Certificate of } \\
\text { conformity OHSMS } \\
\text { (OHSAS 18001/ISO } \\
\text { 45001/NP 4397) }\end{array}$ & $\begin{array}{l}\text { Certificate that guarantees compliance with the Occupational Health \& Safety Management } \\
\text { System (OHSAS 18001/ ISO 45001/NP 4397) }\end{array}$ & & \\
\hline $\begin{array}{l}\text { 25. Certificate of } \\
\text { conformity HRMS } \\
\text { (NP 4427) }\end{array}$ & $\begin{array}{l}\text { Certificate that guarantees compliance with the Human Resources Management System } \\
\text { (NP 4427) }\end{array}$ & & \\
\hline $\begin{array}{l}\text { 26. Certificate of } \\
\text { conformity SRMS } \\
\text { (SA 8000/NP 4469) }\end{array}$ & $\begin{array}{l}\text { Certificate that guarantees compliance with the Social Responsibility Management System } \\
\text { (SA 8000/NP 4469) }\end{array}$ & & \\
\hline $\begin{array}{l}\text { 27. Other } \\
\text { certificates and } \\
\text { registers }\end{array}$ & $\begin{array}{l}\text { Other records or certificates not mentioned in the other subcategories. For example, } \\
\text { product certificates }\end{array}$ & & \\
\hline $\begin{array}{l}\text { C5 -Normative } \\
\text { references, symbols, } \\
\text { and corporate } \\
\text { brands }\end{array}$ & \multicolumn{3}{|c|}{$\begin{array}{l}\text { Recognizable symbols, references or brands "which indicates with a sufficient level of confidence, that the respective product, process or service is in conformity with a norm or other } \\
\text { specific normative document" (NP EN 45020: 2001, p. 35) such as the standards underlying the management systems referred to in the category } 4 \text {. This category also includes other } \\
\text { symbols or references associated with aspects of corporate sustainability such as those related to the environment. }\end{array}$} \\
\hline $\begin{array}{l}\text { 28. Reference, } \\
\text { symbol or brand } \\
\text { QMS (ISO 9001) }\end{array}$ & Reference, symbol or brand indicating compliance with the quality management system & \multirow{6}{*}{$\begin{array}{l}\text { Example - subcategory 28: } \\
\text { "company" organizational system was } \\
\text { developed and implemented according } \\
\text { norm NP EN ISO 9001 and is certified } \\
\text { since } 2004 \text { in the scope of Design, } \\
\text { Engineering and Production of Moulds" } \\
\text { "Management is committed to enforcing } \\
\text { the requirements of NP EN ISO } 9001 \text { and } \\
\text { ISO } 45001 \text { and using them as a factor to } \\
\text { promote Quality, Safety and Health at } \\
\text { Work } \\
\text { Symbol: } \\
\text { SGS }\end{array}$} & \multirow{5}{*}{$\begin{array}{l}\text { Inclusion: Any document presented in the } \\
\text { website (anyplace) or document available for } \\
\text { download and associated with the references } \\
\text { mentioned in the category } \\
\text { Exclusion: Any references, symbol or brand } \\
\text { other than those associated with each of the } \\
\text { subcategories } 28,29, \ldots, 32 \text {. }\end{array}$} \\
\hline $\begin{array}{l}\text { 29. Reference, } \\
\text { symbol or brand } \\
\text { EMS (ISO 14001/ } \\
\text { EMAS III) }\end{array}$ & $\begin{array}{l}\text { Reference, symbol or brand indicating compliance with the environment management } \\
\text { system }\end{array}$ & & \\
\hline $\begin{array}{l}\text { 30. Reference, } \\
\text { symbol or brand } \\
\text { OHSMS (OHSAS } \\
\text { 18001/ ISO 45001/ } \\
\text { NP4397) }\end{array}$ & $\begin{array}{l}\text { Reference, symbol or brand indicating compliance with the Occupational Health \& Safety } \\
\text { Management System }\end{array}$ & & \\
\hline $\begin{array}{l}\text { 31. Reference, } \\
\text { symbol or brand } \\
\text { HRMS (NP 4427) }\end{array}$ & $\begin{array}{l}\text { Reference, symbol or brand indicating compliance with the Human resources management } \\
\text { system }\end{array}$ & & \\
\hline $\begin{array}{l}\text { 32. Reference, } \\
\text { symbol or brand } \\
\text { SRMS (SA 8000/NP } \\
4469\end{array}$ & $\begin{array}{l}\text { Reference, symbol or brand indicating compliance with the Social responsibility } \\
\text { management system }\end{array}$ & & \\
\hline $\begin{array}{l}\text { 33. Other } \\
\text { references, symbol } \\
\text { or brand-related to } \\
\text { corporate } \\
\text { sustainability }\end{array}$ & $\begin{array}{l}\text { Reference, symbol or brand associated with aspects of corporate sustainability such as } \\
\text { those related to the environment }\end{array}$ & & $\begin{array}{l}\text { Inclusion: Any references, symbol or brand } \\
\text { presented in any company website place or } \\
\text { document available for download and not } \\
\text { included in subcategories } 28,29, \ldots, 32 \text {, and } \\
\text { associated to corporate sustainability or with } \\
\text { one of the three dimensions of TBL. They are } \\
\text { included in the subcategory if they do not raise } \\
\text { any doubts of interpretation or are subtitled or }\end{array}$ \\
\hline
\end{tabular}




\begin{tabular}{|c|c|c|c|}
\hline$y$ & & & $\begin{array}{l}\text { inserted in pages or sections related to } \\
\text { corporate sustainability. } \\
\text { Exclusion: excluded those who raise doubts } \\
\text { about their categorization as related to } \\
\text { corporate sustainability }\end{array}$ \\
\hline $\begin{array}{l}\text { C6-Corporate } \\
\text { indexes }\end{array}$ & \multicolumn{3}{|c|}{$\begin{array}{l}\text { Management instruments used to measure and evaluate the performance of the organization in the various areas: economic, social or environmental. These instruments can be qualitative or } \\
\text { quantitative. This category aggregates the different indicators and indexes found on the company's website }\end{array}$} \\
\hline $\begin{array}{l}34 \text { - Indicators and } \\
\text { indexes about } \\
\text { economic/financial } \\
\text { issues }\end{array}$ & $\begin{array}{l}\text { These indicators and indexes reflect the economic performance associated with the } \\
\text { economic dimension of sustainability and refer to the organization's impacts on the } \\
\text { economic conditions of its stakeholders and on the economic systems at local, national and } \\
\text { global levels. This information is usually made available in the financial statements (GRI, } \\
\text { 2006). }\end{array}$ & & $\begin{array}{l}\text { Inclusion: Any indicator or index that consider } \\
\text { the economic dimension of TBL } \\
\text { Exclusion: Any indicator or index that is } \\
\text { related to the social and environmental } \\
\text { dimension of Corporate sustainability. }\end{array}$ \\
\hline $\begin{array}{l}35 \text { - Indicators and } \\
\text { indexes about } \\
\text { corporate } \\
\text { sustainability issues }\end{array}$ & $\begin{array}{l}\text { Performance instruments to measure the commitment, responsibility, results of the } \\
\text { company's policies, objectives, and actions in the area of sustainability, in in the TLB } \\
\text { perspective (economic, environmental and social) }\end{array}$ & & $\begin{array}{l}\text { Inclusion: Any indicator or index that consider } \\
\text { the simultaneously the three dimensions of } \\
\text { TBL. Those that use or refer to the terms } \\
\text { "sustainability", "sustainable development" or } \\
\text { "corporate social responsibility" are included. } \\
\text { Exclusion: All those that refer only to one of } \\
\text { the dimensions of TLB (e.g. environmental). If } \\
\text { they are associated only with social or } \\
\text { environmental aspects, a new category must be } \\
\text { created. If economical, insert in the subcat. } \\
\text { /code } 34 \text {. }\end{array}$ \\
\hline $\begin{array}{l}\text { C7 - Corporate } \\
\text { policies }\end{array}$ & \multicolumn{3}{|c|}{$\begin{array}{l}\text { Company policies that contribute to or show the company's concern for sustainability (considering its various dimensions). This category aggregates the different corporate policies } \\
\text { identified in the subcategories } 36,37, \ldots, 41 \text {, found on the company's website }\end{array}$} \\
\hline 36 - Quality policy & $\begin{array}{l}\text { "set of intentions and guidelines of an organization, related to quality as formally expressed } \\
\text { by top management" (NP EN ISO 9000: 2005, p. 17) }\end{array}$ & \multirow{6}{*}{$\begin{array}{l}\text { Examples - Subcategoriy 36: } \\
\text { "Quality Policy: the company see } \\
\text { Customers as partners, and from this } \\
\text { partnership comes information and } \\
\text { knowledge, which allows for } \\
\text { Organisations to improve...". } \\
\text { "The Quality Policy of Moldetipo II, } \\
\text { Engineering Molds and Prototypes, Lda is } \\
\text { based on three vertices that, although } \\
\text { distinct, are related in a perspective of } \\
\text { Dynamic Growth and Continuous } \\
\text { Improvement: EMPLOYEES, CLIENTS } \\
\text { and SUPPLIERS" }\end{array}$} & \multirow{6}{*}{$\begin{array}{l}\text { Inclusion: Any statement about the mentioned } \\
\text { policies presented in any company website } \\
\text { place or document available for download and } \\
\text { that expressly mentions the policy designation. } \\
\text { Exclusion: Policies other than those associated } \\
\text { with each of the subcategories }\end{array}$} \\
\hline fironmental policy & $\begin{array}{l}\text { "set of intentions and general guidelines of an organization, related to its environmental } \\
\text { performance, as formally expressed by top management" (NP EN ISO 14001: 2012, p. 11). }\end{array}$ & & \\
\hline $\begin{array}{l}38 \text {-Occupational } \\
\text { health and safety } \\
\text { policy }\end{array}$ & $\begin{array}{l}\text { "set of intentions and general guidelines of an organization, related to its performance in } \\
\text { occupational safety and health, as formally expressed by top management" (OHSAS } \\
\text { 18001: 2007, p. 4; NP 4397: 2008, p. 10). }\end{array}$ & & \\
\hline $\begin{array}{ll}\text { Iman resources } \\
\text { policy }\end{array}$ & $\begin{array}{l}\text { "set of intentions and guidelines of an organization, related to human resources, as formally } \\
\text { expressed by top management (adapted from NP 4427: } 2004 \text { and NP EN ISO 9000: 2005) }\end{array}$ & & \\
\hline $\begin{array}{l}\text { 40. Sustainability } \\
\text { policy }\end{array}$ & $\begin{array}{l}\text { set of intentions and guidelines of an organization, related to sustainability as formally } \\
\text { expressed by top management (adapted from GRI, } 2006 \text { and NP EN ISO 9000: 2005) }\end{array}$ & & \\
\hline $\begin{array}{l}\text { 1. Social } \\
\text { responsibility policy }\end{array}$ & $\begin{array}{l}\text { "Declaration of intentions and guidelines of an organization related to social responsibility, } \\
\text { formally expressed by top management" (NP 4469-1: 2008, p. 13) }\end{array}$ & & \\
\hline
\end{tabular}




\begin{tabular}{|c|c|c|}
\hline $\begin{array}{l}\text { C8 - Corporate } \\
\text { programs/ } \\
\text { initiatives/practices } \\
\text { internal, in the scope } \\
\text { of corporate } \\
\text { sustainability }\end{array}$ & $\begin{array}{l}\text { this category aggregates programs/initiatives/policies/practices related to internal issues of } \\
\text { the organization or its internal operations and that refer to corporate sustainability }\end{array}$ & \\
\hline $\begin{array}{l}42 . \\
\text { Programs/initiatives/ } \\
\text { practices related to } \\
\text { human resources } \\
\text { (e.g., health and } \\
\text { safety, employee } \\
\text { welfare, employee } \\
\text { development, equal } \\
\text { opportunity for } \\
\text { employees, human } \\
\text { rights) }\end{array}$ & $\begin{array}{l}\text { Set of programs/initiatives/ policies/practices related to internal issues of the organization } \\
\text { or its internal operations and which seek to ensure human safety and welfare, promote } \\
\text { quality of life, and equal opportunities between people. It includes activities related with } \\
\text { employee health and safety employee welfare, education/training programs, employee } \\
\text { development and equal opportunity for employees, compliance with labour rights, human } \\
\text { rights such as children labour, etc. }\end{array}$ & $\begin{array}{l}\text { "In order to achieve this, it promotes the } \\
\text { involvement of employees and all related } \\
\text { parties in safety and health management, } \\
\text { so that everyone contributes to the } \\
\text { prevention of incidents, injuries and } \\
\text { damages and to comply with the } \\
\text { applicable legal framework" } \\
\text { "...identifies and evaluates the dangers } \\
\text { inherent to its activity in order to minimize } \\
\text { eventual risks and prevent injuries and } \\
\text { health problems, accidents at work and } \\
\text { occupational diseases, therefore } \\
\text { contributing to the workers' quality of } \\
\text { life" } \\
\text { "...focuses on training as a way to develop } \\
\text { both the professional and personal skills of } \\
\text { its employees" }\end{array}$ \\
\hline $\begin{array}{l}43 . \\
\text { Programs/initiatives/ } \\
\text { practices related to } \\
\text { the environment } \\
\text { (e.g., to recycle, } \\
\text { waste management) }\end{array}$ & $\begin{array}{l}\text { Set of programs/initiatives/ policies/practices related to internal issues of the organization } \\
\text { or its internal operations, and which seek to minimize the environmental impact of the } \\
\text { company's activities and the prevention and correction of environmental problems. It } \\
\text { includes activities related with Recycling, Waste management, Energetic efficiency, } \\
\text { Pollution, etc. }\end{array}$ & $\begin{array}{l}\text { "The company thus ensures a set of } \\
\text { adequate practices and behaviours to } \\
\text { maximize energetic efficiency and reduce } \\
\text { greenhouse gas emissions as a result" }\end{array}$ \\
\hline $\begin{array}{l}44 . \\
\text { Programs/initiatives/ } \\
\text { practices related to } \\
\text { products and } \\
\text { services (e.g., } \\
\text { product quality and } \\
\text { safety) }\end{array}$ & $\begin{array}{l}\text { Set of programs/initiatives/policies/practices related to internal issues of the organization or } \\
\text { its internal operations and which seek to improve quality and ensure product safety and } \\
\text { make them more environmentally efficient }\end{array}$ & $\begin{array}{l}\text { "...the client monitors the various stages } \\
\text { of the process and we can easily achieve } \\
\text { the desired result, ensuring high quality } \\
\text { products" }\end{array}$ \\
\hline $\begin{array}{l}\text { 45. Corporate } \\
\text { Governance and }\end{array}$ & $\begin{array}{l}\text { Set of programs/initiatives/policies/practices related to internal issues of the organization or } \\
\text { its internal operations and related with transparency and ethical issues. Includes governance } \\
\text { organizational responsibility/government departments dedicated to corporate sustainability }\end{array}$ & $\begin{array}{l}\text { "...is governed by a proactive culture } \\
\text { towards all stakeholders, multipurpose in } \\
\text { its attitude and responsibility supported by }\end{array}$ \\
\hline
\end{tabular}

Inclusion/exclusion criteria: similar for all

subcategories belonging to this category

Inclusion: any statement that refer activities mentioned in the subcategory, and mentioned expressly in any company website place or document available for download

Exclusion: any statement that does not include the activities mentioned in the subcategory 


\begin{tabular}{|c|c|c|c|}
\hline $\begin{array}{l}\text { ethics (e.g., } \\
\text { transparency) }\end{array}$ & & & \\
\hline $\begin{array}{l}\text { 46. Economic } \\
\text { action (e.g., } \\
\text { corporate } \\
\text { investments) }\end{array}$ & $\begin{array}{l}\text { Set of programs/initiatives/ policies/practices related to internal issues of the organization } \\
\text { or its internal operations and which seek to } \\
\text { include actions related to the economic impact of the enterprise or corporate investments }\end{array}$ & $\begin{array}{l}\text { "the planned investments are intended to } \\
\text { provide the company with new methods } \\
\text { and advanced technological equipment, } \\
\text { which will allow it to strengthen its } \\
\text { presence upstream the chain" }\end{array}$ & \\
\hline $\begin{array}{l}\text { C9. Corporate } \\
\text { programs/initiatives/ } \\
\text { practices of } \\
\text { involvement with } \\
\text { the community and } \\
\text { other stakeholders, } \\
\text { in the scope of } \\
\text { corporate } \\
\text { sustainability }\end{array}$ & $\begin{array}{l}\text { Corporate programs/initiatives/practices which involve the company's involvement with the } \\
\text { community and other stakeholders, namely customers and suppliers, and which seek to } \\
\text { contribute to the improvement of economic, social and environmental conditions }\end{array}$ & & $\begin{array}{l}\text { Inclusion/exclusion criteria: defined for each of } \\
\text { the subcategories belonging to this category }\end{array}$ \\
\hline $\begin{array}{l}\text { 48. } \\
\text { Programs/initiatives/ } \\
\text { practices related to } \\
\text { community } \\
\text { involvement (e.g., } \\
\text { philanthropy and } \\
\text { social involvement) }\end{array}$ & $\begin{array}{l}\text { Activities carried out or supported by the organization in the community in which it } \\
\text { operates, or in which its members reside. It includes many forms of involvement with the } \\
\text { community such as: support for sports associations, supply of products to schools, } \\
\text { hospitals, financial support to non-profit organizations (NGOs) in order to support, charity } \\
\text { and social development. It includes also various forms of participation such as encouraging } \\
\text { workers to get involved; facilitating their participation in social initiatives during normal } \\
\text { working hours; financial, etc. This category includes programs, initiatives, projects or } \\
\text { practices that seek the company's involvement with the community }\end{array}$ & $\begin{array}{l}\text { "Support social and corporate } \\
\text { organizations, both regionally and } \\
\text { nationally" } \\
\text { "We help kids from several institutions" } \\
\text { https://www.macrogroup.eu/en/we-make- } \\
\text { it-real } \\
\text { " }\end{array}$ & $\begin{array}{l}\text { Inclusion: any statement that refer activities } \\
\text { mentioned in the subcategory, and mentioned } \\
\text { expressly in any company website place or } \\
\text { document available for download } \\
\text { Exclusion: any statement that raises doubts } \\
\text { about the company's role in community } \\
\text { involvement activities }\end{array}$ \\
\hline $\begin{array}{l}49 . \\
\text { Programs/initiatives/ } \\
\text { practices related to } \\
\text { suppliers and } \\
\text { customers (e.g., } \\
\text { share information, } \\
\text { technical support) }\end{array}$ & $\begin{array}{l}\text { Corporate programs / initiatives / practices related to corporate sustainability and its } \\
\text { dimensions and that require the company's involvement with its customers and suppliers. } \\
\text { This subcategory includes all activities that seek: to reduce or eliminate the environmental } \\
\text { impact (environmental dimension); to promote community development and protection } \\
\text { from harm and ensure quality of life and equal opportunities between people (social } \\
\text { dimension); to promote economic well-being and standards of living of stakeholders } \\
\text { (economic dimension) }\end{array}$ & $\begin{array}{l}\text { "promoting cooperative relations with } \\
\text { customers, suppliers and the environment } \\
\text { thus contributing to the development of } \\
\text { society } \\
\text { "Sustainability, development of new } \\
\text { techniques, process innovation and quality } \\
\text { are our way to develop partnerships with } \\
\text { our customers" }\end{array}$ & $\begin{array}{l}\text { Inclusion: any statement that refer the } \\
\text { existence of interactions (or similar terms such } \\
\text { as } \\
\text { relations/patnerships/relationships/cooperation/ } \\
\text { colaboration) with suppliers or customers that } \\
\text { contribute to corporate sustainability. } \\
\text { Statements can be mentioned in any company } \\
\text { website place or document available for } \\
\text { download. If a statement about an initiative / } \\
\text { practice is made in the same sentence in which } \\
\text { customers and suppliers are referred to } \\
\text { simultaneously, it must be coded as an } \\
\text { initiative for each of the stakeholders } \\
\text { Exclusion: any statement where consumers or } \\
\text { suppliers are not expressly mentioned }\end{array}$ \\
\hline
\end{tabular}




\section{RESPONSE TO EDITOR AND REVIEWERS}

\section{Dear Editor,}

We would like to thank the Editor and the Reviewers for carefully examining our work entitle: "ONLINE SUSTAINABILITY DISCLOSURE OF MOULD COMPANIES" and for providing us with the opportunity of revising and improving the manuscript. We have addressed all the comments and suggestions of the Reviewers and modified the paper accordingly. All the modifications are marked in blue colour in the revised manuscript in order to facilitate the review process. Thank you very much.

Please see below our detailed responses to every single comment raised. Thanking again for the attention given to this work, we look forward to hearing from you soon.

Yours sincerely, The Authors

\section{REVIEWER 1}

Additional Questions: 1. Originality: Does the paper contain new and significant information adequate to justify publication?: The paper contains elements of significant information that justify publication.

2. Relationship to Literature: Does the paper demonstrate an adequate understanding of the relevant literature in the field and cite an appropriate range of literature sources? Is any signficant work ignored?: The paper contains recent and relevant literature that elaborates the currents state of the research in this area.

3. Methodology: Is the paper's argument built on an appropriate base of theory, concepts, or other ideas? Has the research or equivalent intellectual work on which the paper is based been well designed? Are the methods employed appropriate?: The adoption of Content Analysis methodology for this study is considered appropriate.

4. Implications for research, practice and/or society: Does the paper identify clearly any implications for research, practice and/or society? Does the paper bridge the gap between theory and practice? How can the research be used in practice (economic and commercial impact), in teaching, to influence public policy, in research (contributing to the body of knowledge)? What is the impact upon society (influencing public attitudes, affecting quality of life)? Are these implications consistent with the findings and conclusions of the paper?: This paper shines a light in an industry that is not well known or appreciated. Therefore, its informative angle would be a source of new education for policy makers and contribute to our knowledge of the mould industry and its role in economic activities.

5. Quality of Communication: Does the paper clearly express its case, measured against the technical language of the field and the expected knowledge of the journal's readership? Has attention been paid to the clarity of expression and readability, such as 
sentence structure, jargon use, acronyms, etc.: I believe the paper and the study from a rather remote industry would appeal to the journal's readership.

Ansewer: Thank you for you supporting and valuable comments. We improve the paper following your comment on question 4. You can find in blue the major changes made in the document.

Results: Are results presented clearly and analysed appropriately? Do the conclusions adequately tie together the other elements of the paper?: The paper as currently written is presented in a logical manner, but would require improved writing to advance the presentation and appeal to a wider readership.

Ansewer: Thank you for your remark. The text was proof edited.

\section{REVIEWER 2}

Please see my comments within each category. I hope this feedback is helpful for the ongoing development of the manuscript. Best wishes with your work.

1. Originality: Does the paper contain new and significant information adequate to justify publication?: This paper's stated purpose is to investigate online sustainability disclosure among different sized Portuguese mould companies. Specifically, the researchers conducted a content analysis of corporate websites to examine information disclosure about environmental, social, and economic aspects of sustainability. I do think this is an interesting topic with potential to make a contribution to both theory and practice.

Examining a niche area/industry sector offers a more focused look, but there are also limitations with the applicability of these findings.

Overall, I think the paper offers some new and significant information, but I also have some feedback intended to aid with the continuing development of the manuscript, most notably in the literature and discussion sections. Comments and suggestions are highlighted in the appropriate sections below

Ansewer: Thank you for you supporting and valuable comments. We improve the paper following your comment on the additional questions. You can find in blue the major changes made in the document.

2. Relationship to Literature: Does the paper demonstrate an adequate understanding of the relevant literature in the field and cite an appropriate range of literature sources? Is any signficant work ignored?: In this reviewer's opinion, the arguments in the literature review need more elaboration and terms need to be more clearly explicated.

For example, the introduction immediately introduces the term "corporate sustainability (CS)" without further explication. Then the term "sustainability" is used, and references to "sustainability/Corporate Social Responsibility (CSR)" is used. While it is noted that the authors later define CS in the next section, a brief definition should be provided earlier along with some context related to how the authors position their approach. Arguably, as one example, sustainability is conceptually different (although tangentially related) from CSR, and CS adds another dimension. The authors argue that CS and CSR are often used interchangeably (citing Reilly and Larya, 2018), but I encourage the authors to broaden their literature search, as several other scholars argue there are clear distinctions between 
the terms. The authors need to clearly distinguish between concepts and demonstrate an understanding the differences in reporting content and practices. The subsequent discussion about stakeholder theory is more cohesive, and Table 1 and the list of areas/dimensions offer a helpful summary. This is perhaps the most robust section of the literature review.

Ansewer: Thank you for this important comment. To clarify the concepts (sustainability, corporate sustainability and corporate sustainability), at the beginning of the Introduction section, a paragraph was introduced and the definition of corporate sustainability (it was previously presented at the beginning of section 2.1) was replaced to here.

In addition, we rewrote the initial part of section 2.1, to make the approach used in the paper more explicit.

(question 2 cont).

I read over the "Research Questions" section several times, and each time I have questioned whether the authors might consider reordering the RQs. RQ1 as it is currently written focuses solely on sustainability-related documents. Then R2 and H1 discuss the amount of information relative to company size, and finally RQ3 focuses on type of information that is disclosed. I'm inclined to suggest the authors reworking this to first start by asking about the amount of information on the websites. Furthermore, I feel that RQ2 and H1 are redundant. I feel that the authors could tell a better story by first asking about the amount of content and then hypothesizing about the relationship between the amount of information and company size. Then perhaps the current RQ3 could be written to focus on the type of content. Finally, then, the more specific question about whether the companies provide sustainability-related documents and the formats used could be discussed.

Ansewer: Thank you for your comment and suggestions. In fact, we cannot change the RQs order. This because, in the sampling process we do not consider the inexistence of sustainability-related documents as an exclusion criterion. So, in the first step is necessary to identify if the companies belonging to the sample communicate information related to sustainability. We find out that in from the 83 companies under study, only 1 company do not communicate any information related to sustainability.

We add the following text:

"To study the online sustainability disclosure of Portuguese mould companies a three-step research design was used. First, we would verify if the companies belonging to this sector provide on their websites documents related to sustainability. In a second step, and for the companies that disclose information related to sustainability, we would like to verify if company size is a factor that affects the amount of sustainability information disclosed by companies. Finally, we want to know what type of sustainability-related information is disclosed by companies on their websites. The next paragraphs present the rationale behind this research design and the research questions that will guide the data collection procedure."

3. Methodology: Is the paper's argument built on an appropriate base of theory, concepts, or other ideas? Has the research or equivalent intellectual work on which the paper is based been well designed? Are the methods employed appropriate?: Overall, this section is wellarticulated, and I applaud the authors for the detail provided. Specifically, it is very helpful 
to know the number of companies (740, as of 2017) that comprise the mould industry and how roughly $11 \%$ of that total number were included in this present study's final sample. The sampling procedure was described sufficiently. I was surprised to learn there was only one large-size Portuguese company in the mould industry. I do think this limitation needs to be considered and that the results and discussion put this into context. The authors selected the sample by choosing the top 100 companies in a given industry sector (with a final sample of 83 after some exclusions). This creates uneven categories for each company size category (large, micro, small, medium). Given the emphasis on the impact of company size on predicted outcomes, more justification is needed for the sampling selection. Also, a list of the 83 companies that were included in the sampling frame would be helpful (perhaps in the Appendix).

Ansewer: Thank you for the comment. A list of the companies analysed with their dimension and website is included in the Appendix A.

From the universe of 740 companies (in 2017), we narrow our study to the 100 companies identified by the Portuguese Business Association as the ones having best performance. We build our sample from this sub-set of 100 companies.

(question 3 cont).

I suggest removing Figure 1. While it is a helpful step-by-step guide for the content analysis process, I don't think it is necessary to include for publication. I would also remove introductory sentences that describe the steps such as the first sentence on p. 9 ("One of the main steps in a content analysis is the definition..."). Simply state what the authors did as part of the step. The introductory sentences may read like a textbook or "how-to" guide to some readers. This applies to several areas throughout the manuscript

Ansewer: Thank you for the remark. We remove Figure 1 and change the text according to your instructions.

(question 3 cont).

I applaud the authors for examining the entire website (including documents available for download). Few studies have been as comprehensive, and I think this is a strength of your study.

Please include a copy of your code book in an appendix.

Ansewer: Thank you for the comment. We add our codding book in an appendix B.

(question 3 cont).

While I appreciate the authors' careful approach to coding, my biggest concern is the lack of reporting information about an intercoder reliability test. This information needs to be added, inclusive of the reliability statistic and $\operatorname{method}(\mathrm{s})$ used to calculate that.

Ansewer: Thank you for your useful comment. In fact, because of the limited size of the sample and the reduced volume of sustainability-related information available, both coders analyzed the 83 websites in the sample and any divergence was resolved during data collection. We add in the text the following text: 
"To assure data reliability a coding book was developed to support the research process (Appendix B). Nili et al. (2017) refers that when selection a method to calculate the intercoder reliability in content analysis the type of data and the agreement level between two or more independent coders should be taken into consideration. In our research, we used only a nominal scale (i.e. "yes/no") to check if a category or item is present or absent in a website; also we used an interval scale to count the number of pages used by companies in their website to communicate sustainability-related information. Two native speakers of Portugal coded all the websites; this, was possible because of the sample size and the limited sustainability-related information available in the company's website. In this way, any disagreement between coders was solved during the codding, when necessary the category and item was refined in the coding book".

4. Results: Are results presented clearly and analysed appropriately? Do the conclusions adequately tie together the other elements of the paper?: The results are robustly reported. However, I recommend that the section be further organized to more explicitly address each RQ and H1. As the section currently reads, it's not as explicitly clear which results pertain to which RQ. Furthermore, I would suggest separating the "Result and Discussion" section into two separate "Results" and "Discussion" sections where the researchers can elaborate on implications for theory, practice, and society. For example, much of what appears on p. 16 could be incorporated into the discussion section. Of course, if the authors reorder the RQs, the results section should reflect those changes, too.

Ansewer: Thank you for your comment. We organized section 5 in three subsections. In each one we present the results, the response to the respective $R Q$ and then the discussion.

5. Implications for research, practice and/or society: Does the paper identify clearly any implications for research, practice and/or society? Does the paper bridge the gap between theory and practice? How can the research be used in practice (economic and commercial impact), in teaching, to influence public policy, in research (contributing to the body of knowledge)? What is the impact upon society (influencing public attitudes, affecting quality of life)? Are these implications consistent with the findings and conclusions of the paper?: The authors offer some practical implications, but more attention to the theoretical implications section is necessary. For example, how, specifically, does this relate to findings from extant literature regarding stakeholder theory in a CS context?

What new contributions did the paper make?

It is especially important to highlight the contributions of investigating mould companies in a particular geographical area and how this particular study's approach adds originality/value to the existing body of literature.

More substantive discussion would also strengthen the paper, as the data offer more than is being discussed. Finally, I recommend moving the limitations noted at the top of p. 17 to the end of the section (after practical implications).

Ansewer: Thank you for the comment. We added in conclusion section the following text:

"Despite these limitations, our study contributes to the knowledge of sustainability communication practices in SMEs, an area of research that needs to be more explored (Fifka, 2012; Mura et al., 2019) and in an industry (moulds) that have not received much attention in this area. Although SMEs have very strong social importance and impact in the global and economy (Dias et al., 2019), research on corporate sustainability has 
focused on large companies, with corporate sustainability in SMEs companies comparatively a less researched area (Das et al., 2020). With regard to corporate sustainability communication, the literature highlights that SMEs often lack in communicating their activities (e.g. social and environmental) in the scope of corporate sustainability to their stakeholders (Das et al., 2020). This study contributes to the literature on corporate sustainability communication in SMEs, increasing knowledge about the type and extent of corporate sustainability activities developed and reported by this type of companies and in a specific industry (moulds) that have not received much attention in this area. Thus, the authors believe that this study can also be a stimulus for future research in sectors that have been little studied.

Moreover, this study by providing the state-of-the-art of the online sustainability disclosure of companies contributes to tracking the progress towards the achievement of the 17 SDS goals of the 2030 Agenda for Sustainable Development (Tsalis et al., 2020). The conclusions of this study make possible to confirm also whether the rising interest in sustainability reporting, not only from governments but also from investors and stock exchanges, by creating regulatory instruments and incentives for reporting has encouraged the disclosure of sustainability information (Shoaf et al., 2018).

6. Quality of Communication: Does the paper clearly express its case, measured against the technical language of the field and the expected knowledge of the journal's readership? Has attention been paid to the clarity of expression and readability, such as sentence structure, jargon use, acronyms, etc.: The manuscript does not read as smoothly as it could. Sentence structure could be improved, as well as the way the information within each section is organized. There are several typographical errors (as just one example, there are iterations of "mold," "mould," and "moulds" to describe the industry that is being investigated in the study). I recommend that the authors thoroughly proofread the manuscript and consistently adhere to the journal's stylistic guidelines, as well.

Ansewer: Thank you for the comment. The paper was fully revised.

\section{REVIEWER 3}

It was a pleasure to read the above manuscript and to learn a few things about the mould industry in Portugal. The paper was informative especially in the attempt to highlight the role of this industry in the wider Portuguese economy. Given its importance in the economy, I welcome the opportunity that this manuscript has taken to shine some light in its sustainability disclosure and social responsibility.

The literature coverage appears acceptable and with recent literature included there is the sense of the currency of this effort that will appeal to the readership of the Journal.

Further, I welcome the use of Content Analysis as the methodology of choice for this study. Below, I offer some comments that I hope the author(s) could engage to improve the overall quality of their manuscript. I present these as two major concerns and some minor items:

Ansewer: Thank you for your encouragement and opportunity to improve the paper. You can find in blue the major changes made in the document.

1.I was unable to identify the key contributions of this paper in advancing current knowledge outside the mere revelation of the limited sustainability disclosures that the 
mould industry has made. I encourage the author(s) to dig deeper into their study to identify how their current effort advances our knowledge of sustainability disclosures, its impact and motivations.

Ansewer: Thank you for the remark. The contributions of our study were highlighted in order to make them clearer. In the conclusions, it was written:

"Despite these limitations, our study contributes to the knowledge of sustainability communication practices in SMEs, an area of research that needs to be more explored (Fifka, 2012; Mura et al., 2019) and in an industry (moulds) that have not received much attention in this area. Although SMEs have very strong social importance and impact in the global and economy (Dias et al., 2019), research on corporate sustainability has focused on large companies, with corporate sustainability in SMEs companies comparatively a less researched area (Das et al., 2020). With regard to corporate sustainability communication, the literature highlights that SMEs often lack in communicating their activities (e.g. social and environmental) in the scope of corporate sustainability to their stakeholders (Das et al., 2020). This study contributes to the literature on corporate sustainability communication in SMEs, increasing knowledge about the type and extent of corporate sustainability activities developed and reported by this type of companies and in a specific industry (moulds) that have not received much attention in this area. Thus, the authors believe that this study can also be a stimulus for future research in sectors that have been little studied.

Moreover, this study by providing the state-of-the-art of the online sustainability disclosure of companies contributes to tracking the progress towards the achievement of the 17 SDS goals of the 2030 Agenda for Sustainable Development (Tsalis et al., 2020). The conclusions of this study make possible to confirm also whether the rising interest in sustainability reporting, not only from governments but also from investors and stock exchanges, by creating regulatory instruments and incentives for reporting has encouraged the disclosure of sustainability information (Shoaf et al., 2018)."

2.I would encourage the author(s) to take serious steps to up their writing a notch or two. The manuscript as currently written is difficult to read in several places and the confusing use or mix up of terms such as: "moulds industry/companies", "mould industry/companies". I have opted not to point out the relevant pages, it's just all over. A full and comprehensive editing of the manuscript would help the readability and bring out the full importance/impact of the study that you are attempting to advance.

Ansewer: Thank you for this remark. The paper was proofread.

\section{Other items:}

3a. Of the 83 SMEs/companies analyzed - are these publicly-listed companies? Do they have an obligation to disclose CS/CSR information? Would their motives for disclosure be ascertainable from their disclosures? OK.

Ansewer: Thank you for raising this important question. We clarify this aspect in section 4.1:

"In what is related to the motivations of companies to disclose information related to sustainability, it is necessary to notice that EU directive 2014/95 / EU, transposed into 
Portuguese law in 2017, states that companies (publicly listed companies, banks, insurance companies and companies designated by national authorities as public-interest entities), with at least 500 employees, must disclose non-financial information (e.g. regarding environmental protection, social responsibility, and treatment of employees, human rights). None of the 83 companies is covered by this or other legislation that requires disclosure information regarding their sustainability credentials. By law, Portuguese SMEs (excluding micro-entities) are only required to report financial information."

3b. I recognize that Table 6 and 7 are closely related. However, Table 7 would be more helpful with a few sentences that explain the relative importance of the sustainability dimensions and how that compares to the overall direction of disclosures made by the moulds industry in Portugal.

Ansewer: Thank you for this comment. We clarify the differences between Table 6 and Table 7. Also, we include in Table 6 examples of the information disclosed in the company's website for better understanding:

"It should be noticed a major difference between Table 6 and Table 7: in the first one, we find the number of companies in sample that, for each sustainability disclosure dimension, communicate information at least one time; in the second one, we find the number of companies that disclosure information for each item. Therefore, in Table 7 we can have more than one entry for each company; this provides an indication of the diversity of information that companies use to communicate sustainability in their websites. For example, in Table 6 we find that the information related to the dimension "Community involvement" is disclosed by six companies in the sample. From the evidence column, we find that company labelled by "[COM81]" disclose information related with two items "Sponsoring sporting or recreational projects" and "Support for education". These two items appear in Table 7." 